د/ هبه الله مصطفى محمد مصطفى

\title{
الاتجار بالنساء العاملات في الخدمة المنزلية الأسباب وسبل المواجهة: دراسة حالة بمحافظة القاهرة
}

د/ هبه الله مصطفى محمد مصطفى

مدرس علم الاجتماع - كلية التربية - جامعة عين شمس مدم مدمى

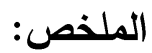

هدفت الدراسـة الحاليـة إلى فحص ظـاهرة استغلال النسـاء العـاملات في الخدمـة

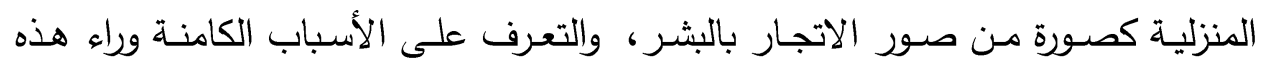
الظـاهرة، والآثار المترتبة عليها، من أجل الوصـول إلى أسـاليب لمواجهة هذه الظـاهرة.

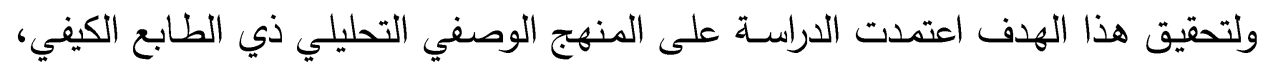

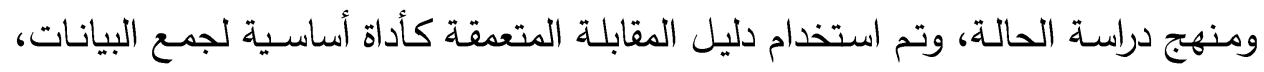
بجانب الملاحظة، واعتمدت على عينة عمدية مكونة من 10 حالة من النساء العاملات في الخدمة المنزلية في محافظة القاهرة، وروعي في اختيارهن التتوع في السن، والمستوى

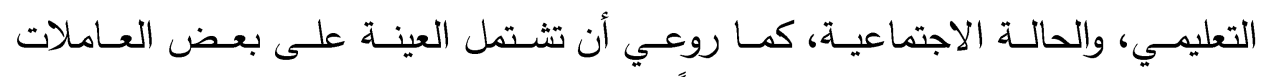

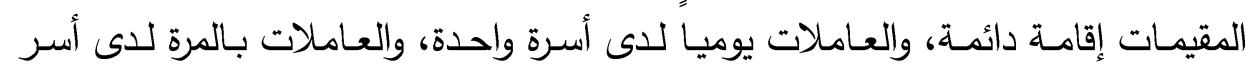

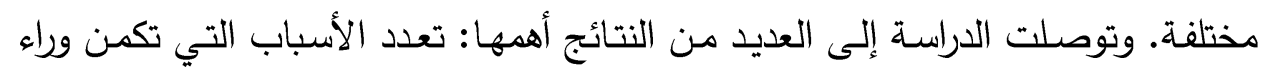
اندفاع النساء للعمل في الخدمة المنزلية، وأهمها الفقر وانخفاض مستوى التحصيل العلمي التئي ومستوى التأهيل المهني مما يجعلهن يتجهن إلي خلق فرص تشغيل ذاتي ضمن قطاع

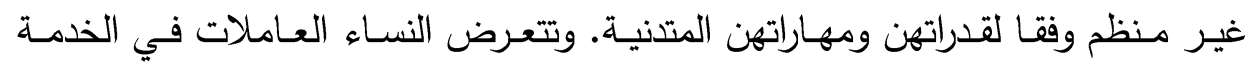

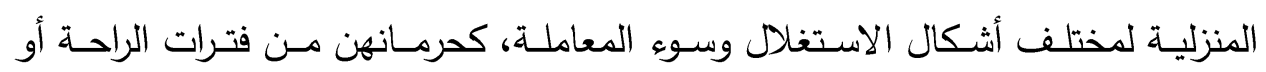
الإجـازات، وعدم دفع أجورهن أو اقتطاعها, وتتعرض بعضـهـن للضـرب والتحرش بهن.

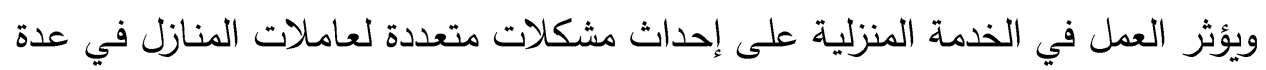
جوانب اجتماعية ونفسية وصحية. الكلمات المفتاحية: العاملات في الخدمة المنزلية, الاتجار , الاستغلال, التسلع.

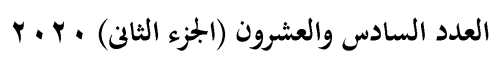

مجلة مجلة كلية التربية- جامعة عين شمس 
الاتجار بالنساء العاملات في الخدمة المنزلية الأسباب وسبل المواجهة: دراسة حالة بمحافظة القاهرة

Trafficking of women working in domestic service, causes and means of confrontation: a case study in Cairo Governorate Dr/ Heba allah Mustafa Mohamed Mustafa Lecturer of Sociology Faculty of Education, Ain Shams University

\section{Abstract:}

The current study aims at investigating the phenomenon of exploitation of female domestic workers as a form of human trafficking, and to identify the reasons behind this phenomenon, and the effects of it, in order to find methods to address this phenomenon. To achieve this aim, the study depends on the qualitative and analytical descriptive methodology and the case study method. The study used the interview guide as the main tool for collecting data, besides observation, and it was based on an intentional sample of (10 cases) female domestic workers in Cairo Governorate, their selection took into account the diversity of age, educational level and social status. The sample also included some permanent workers, daily workers of one family, and workers of different families. The study found many results that are the most important of it: the multiple reasons behind the rush of female to work in domestic service, the most important of which are poverty and low level of educational attainment and professional qualification, which leads them to create self-employment opportunities in the informal sector according to their low abilities and skills. And female domestic

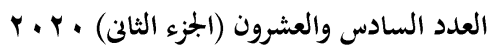

$$
\begin{aligned}
& \text { ججلة ججلة كلية التربية- جامعة عين ثنمس }
\end{aligned}
$$


د/ هبه الله مصطفى محمد مصطفى

workers are exposed to various forms of exploitation and maltreatment, such as being deprived of periods of rest or leave, not being paid or withheld, and some being beaten and harassed. Also domestic work led to create multiple problems for female domestic workers in several social, psychological and health aspects.

Keywords: domestic workers, trafficking, exploitation, merchandising. 
الاتجار بالنساء العاملات في الخدمة المنزلية الأسباب وسبل المواجهة: دراسة حالة بمحافظة القاهرة

\section{الاتجار بالنساء العاملات في الخدمة المنزلية الأسباب وسبل المواجهة: دراسة حالة بمحافظة القاهرة}

د/ هبه الله مصطفى محمد مصطفى

مدرس علم الاجتماع - كلية التربية - جامعة عين شمس مصلم

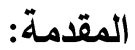

إن ظاهرة الاتجار بالبشر ليست وليدة السنوات الأخيرة التي ظهر فيها مصطلح

الاتجار بالبشر بل هي ظاهرة تاريخية عرفتها الجماعة الإنسانية منذ القدم في صورة ما عرف بنظام الرق والاستعباد. فقديما في العصر الجاهلي كانت تقام مزادات علنية لبيع العبيد، وكانوا يعاملون وكأنهم سلع يتم تداولها بالأسواق تشترى للقيام بالأعمال الخدمية لهية

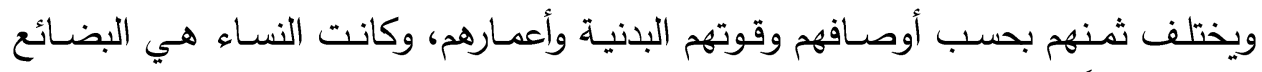
الأكثر حظا حيث كانت تباع إما لممارسـة الرذيلة، وإما للعمل في المزارع وأعمال الخدمة

ويعد الاتجار بالبشر جريمـة ضـد الإنسانية لمـا تتطوي عليه من تسليع الإنسـان وجعله محلا للعرض والطلب ويمكن تداوله واستغلاله بكافة الوسائل غير المشروعة وذلك بمـا يخـالف تعـاليم الأديـان السماوية، فقد جـاءت الشريعة الإسـلامية بنظـام يحرم الـرق والاستعباد، حيث خلق الله الإنسان وفضله على سائر الخلق في قوله تعالى:" ولقد كرمنا بني آدم وحملناهم في البر والبحر ورزقناهم من الطيبات وفضلناهم على كثير ممن خلقنا تفضيلاً" (سورة الاسراء,الآية • V), وقال أمير المؤمنين عمر بن الخطاب رضئ رضي الله عنه:

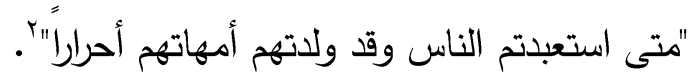

'إبراهيم الدراجي، مواجهة الاتجار بالأثخاص في القوانين والتثريعات السورية - دراسة قانونية، منشورات المنظمة الدولية

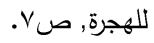

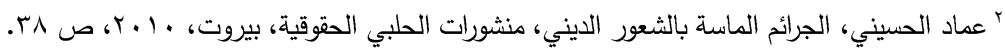

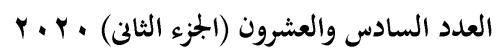

(206)

مجلة مجلة كلية التربية- جامعة عين شمس 
فقد أصبحت ظاهرة الاتجار بالبشر ظاهرة مجتمعية محلية وعالمية مؤرقة، فهي الوجه العصري لظاهرة الرق والعبودية، وتمثل انتهاكا صريحاً لحقوق الإنسان بما تتطوي عليه من إمتهان لكرامة الإنسان وآدميته، فهو في جوهره يخرق حق الإنسان الثامل في لي

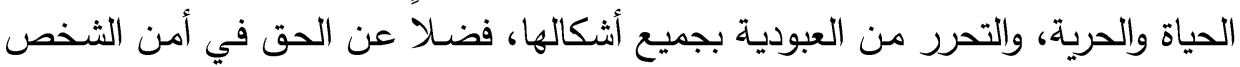

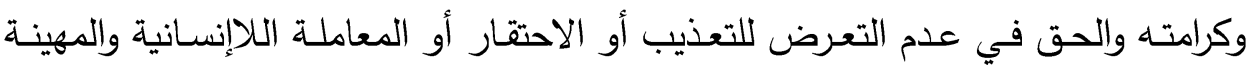

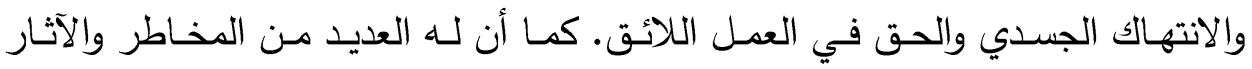
السلبية على الإنسان بصفة عامة، وعلى المجتمعات بصفة خاصةّ؛ّ وتعتبر ظاهرة الاتجار بعاملات المنازل واستغلالهن غير المشروع في كثير من الإنهات

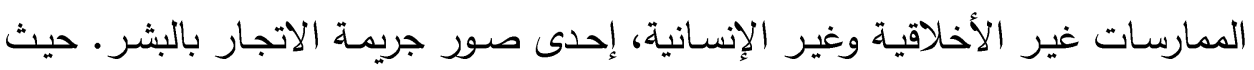

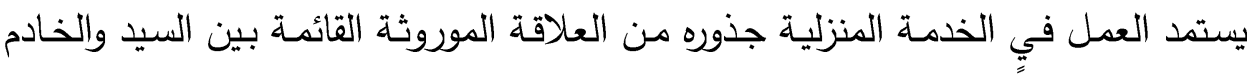

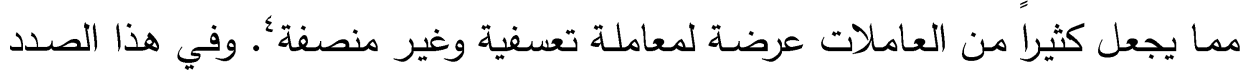

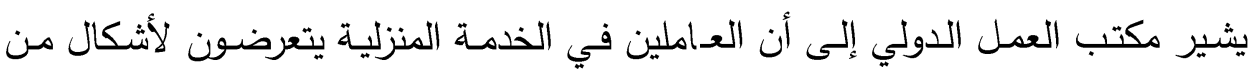

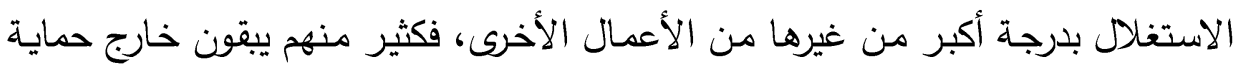

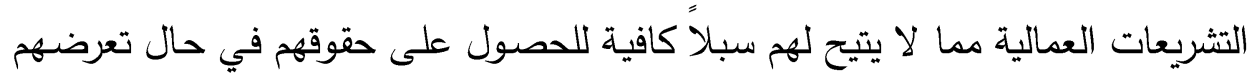
لملاستغلال أو الإيذاءه

" خالد بن محمد الدوغان، الإتجار بالبشر وموقف الثريعة الإسلامية منه، المجلة العلمية لجامعة الملك فيصل - العلوم الإنسانية

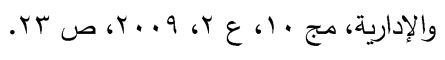

${ }^{4}$ International Labor Office, Gender and migration in Arab states: The case of domestic workers, Geneva: ILO, 2004.

${ }^{5}$ J. Budd, Achieving decent work by giving employment a human face. Geneva: International Labor Office, 2004, p.1.

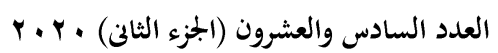

مجلة بجلة كلية التربية- جامعة عين شثس 
الاتجار بالنساء العاملات في الخدمة المنزلية الأسباب وسبل المواجهة: دراسة حالة بمحافظة القاهرة

أولا: الإطار النظري للدراسة:

ا - موضوع الاراسة:

ترتبط ظـاهرة الاتجار بالبشـر بنظـام العولمـة التي فتحت الباب لتجارة استغلالية

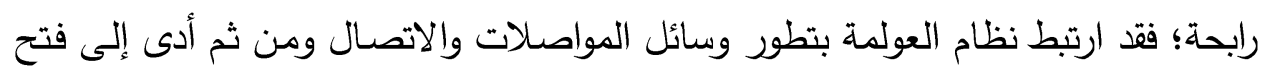

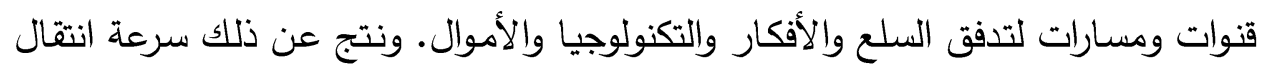

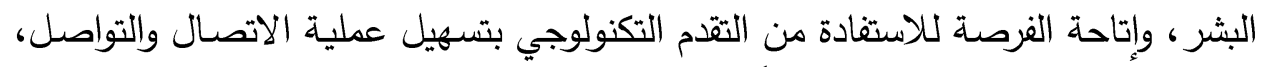

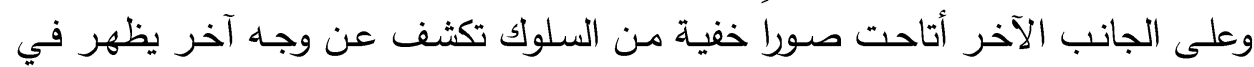
الاستغلال والقهر مـن جانب بعض البشر على آخرين أضـفف مـنهم، حيث يستخدم الأوائل أدوات العولمة ومنجزاتها في تحقيق مكاسبهه، ويدفع الآخرون الثمن من حياتهم

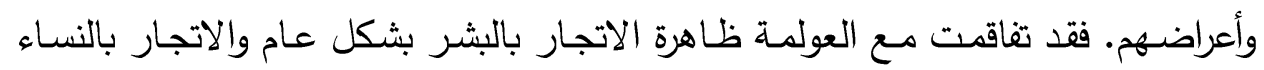
بشكل خاص وأصبحت تجارة رابحة، وأداة لتحقيق الأرباح وتراكم النقود، وفي هذا السياق بأن

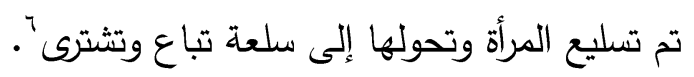
ويرجع استغلال النساء العاملات في الخدمة المنزلية بثكل كبير إلى أن العمل في ونئي

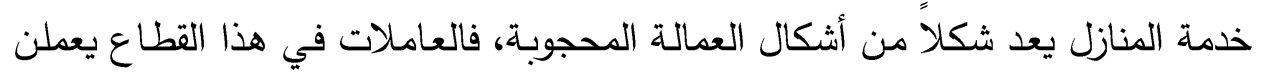
في عزلة وفي أماكن مغلقة وهو ما يعرضهن للإساءات الجسدية والنفسية والجنسية بسبب

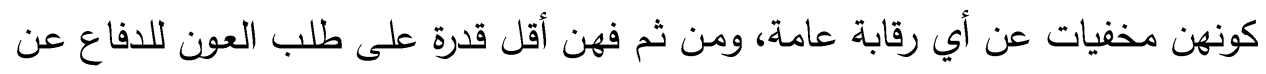

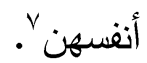

وتتعدد مظـاهر الإسـاءة إلى النسـاء العـاملات في الخدمـة المنزليـة واستغلالكهن،

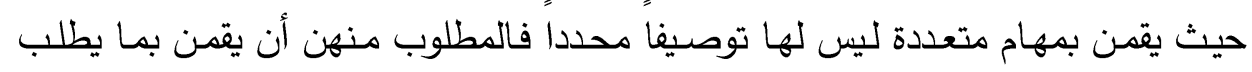

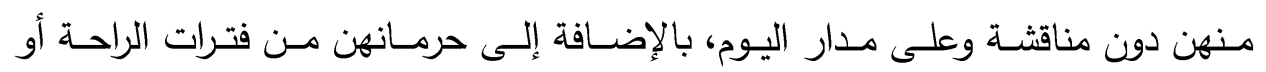

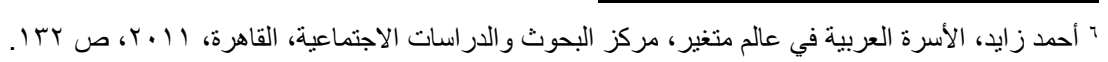

${ }^{7}$ Roberts, D. (1997). Spritual and menial housework. Yale Journal of Law and Feminism, 9 (51), 22-36.

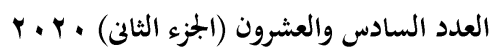

(208)

مجلة بجلة كلية التربية- جامعة عين شثس 
الإجـازات الأسـبوعية والسـنوية والمرضـية، وإن تـوافرت فهي محدودة، كما تحـرم العديـد مـن العـاملات مـن الاحتياجـات الأساسـية مثل: الغـذاء، والتواصل مـع عـائلاتهم، وليس لكثير مـنهن الحق في الخصوصسية، كذلك يتعـرض العديــ مـنهن للإعتداء الجسـدي، واللفظي، والجنسي، . ولا يوجد لهن رعايـة أو تأمين صدي ضد الأمـراض أو المخـاطر التي يتعرضن لها، كما لا يتوافر لهن خدمات تأمينية أو معاشـات وذلك لغياب الإطار القانوني الذي ينظم العلاقة بين خادمات المنازل وأصحاب العمل . وهناك العديد من الأسباب والعوامل التي تدفع عـاملات المنـازل لتحمل الإسـاءة والاستغلال الواقع عليهن من صاحب العمل ومنها: : 1 الفقر

مدـا لا شـك فيـه أن الظـروف الاقتصـادية السيئة، أو الفقر هـ العامـل الأساسـي

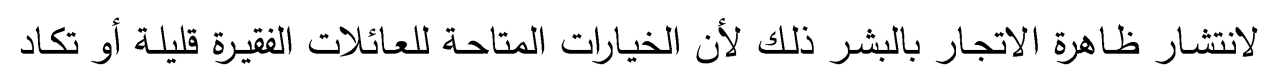
تكـون منعدمـة ولصعوبـة تـأمين دخل أفضـل ونتيجـة للوعـود التي يقطعها تجـار البشـر للضحايا من معيشة أفضل وفرص عمل جيدة يتم الإيقاع بهم والتلاعب بهم '. فكثير من العاملات في الخدمة المنزلية يلجأن للعمل في هذا القطاع للفتر والعوز وضيق ذات اليد وهو ما يزيد من إمكانية استغلالهن بأشكال مختلفة لعدم قدرتهن على دري الاستغلال من ناحية ولحاجاتهن للاستمرار في العمل لإعالة أنفسهن وذويهن من ناحية أخرى'". وفي جميع أنحاء العالم، أثبتت البحوث على الدوام الصلة القوية بين فقر النساء في القطاعـات التي تتعدم فيها حقوق العمل والعمل اللائق، مـن قبيل قطـاعي اقتصـاد

8 Fauve- Chamoux, A. (2004). Domestic service and the formation of European identity: understanding the globalization of domestic work in 16th -21 st centuries. Bern: Peterlang.

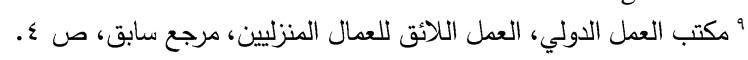

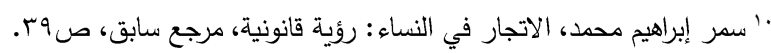

${ }^{11}$ Safitri, M, Abdulrahman, N, \& Rokoduru, A. (2008). The hidden pillars: A study on the contribution of Indonesian domestic workers to the quality of life of Hong Kong and Malaysian Employers. A Project of Asia Pacific Forum on Women, Law and Development's Labor and Migration Task Force, Thailand.

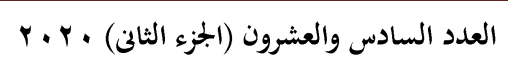


الاتجار بالنساء العاملات في الخدمة المنزلية الأسباب وسبل المواجهة: دراسة حالة بمحافظة القاهرة

الرعاية وخدمات الفنادق والمطاعم حيث تخضـع العاملات للسخرة وتؤدين وظائف تأتي

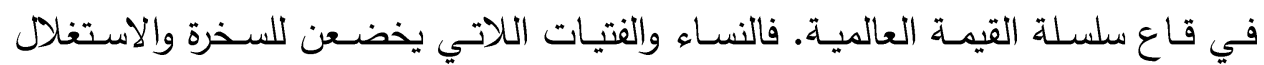
يتعرضن لتهديدات بالعنف الجنسي والعنف البدني, وتصادر أجورهم ويحبسون في أماكن

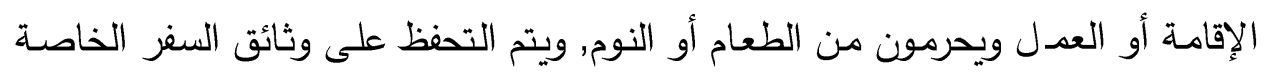

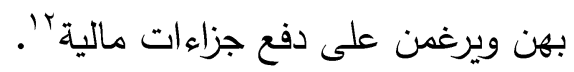

$$
\text { r- التفكك الأسري: }
$$

تعد الأسـرة الوحدة الاجتماعيـة الأولى التي ينشـأ فيها الفرد، ويكتسب منهـا قيمـهـ

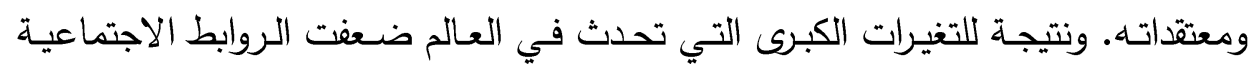

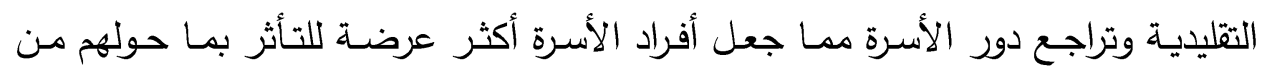

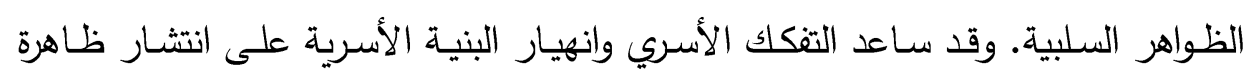

الاتجار بالنساء وخاصة العاملات في الخدمة المنزلية'.

ويزداد استغلال الخادمات اللاتي يأتين من بلدان أو مناطق أخرى بعيدة عن مكان

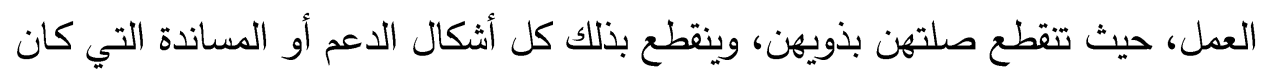

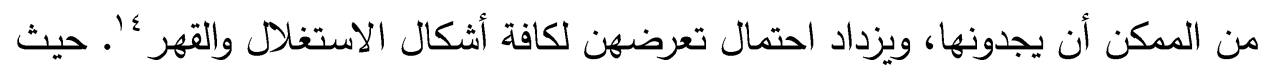

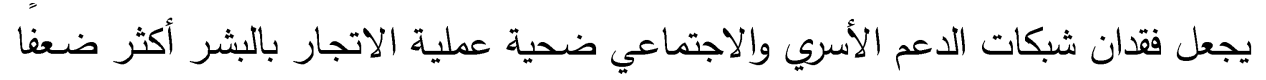

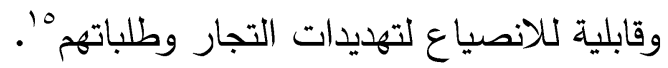

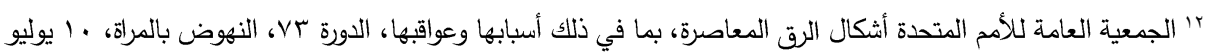
11.

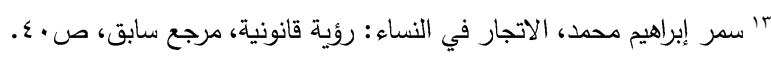
${ }^{14}$ Safitri, M, Abdulrahman, N, \& Rokoduru, A. The hidden pillars: A study on the contribution of Indonesian domestic workers to the quality of life of Hong Kong and Malaysian Employers, op,cit.

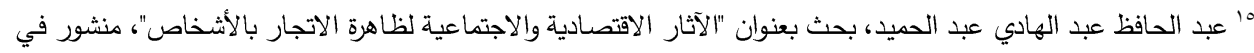

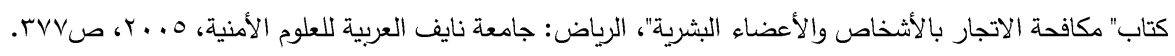

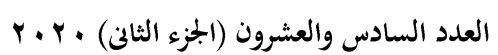

(210)

مجلة مجلة كلية التربية- جامعة عين شمس 
د/ هبه الله مصطفى محمد مصطفى

r- فرص التعليم والعمل غير الكافية:

يعد مستوى التعليم لضـحايا الاتجار منخفضـا بشكل عـام، وخاصـة عند النسـاء.

وهذا يعني انخفاض مستوى المهارات عامة لديهم، مما ينعكس بدوره على نوع العمل الذي

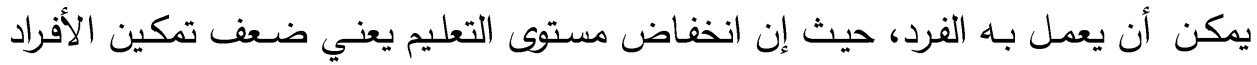

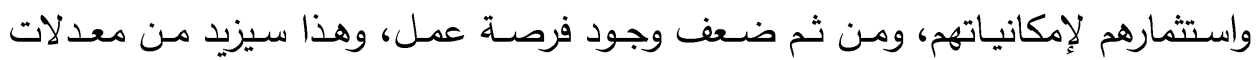

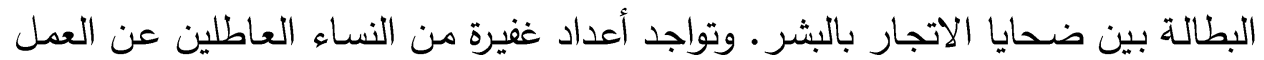
من ذوي المؤهلات المتواضعة والذين يعيشون في فقر مدقع وظروف حياتية سيئة يجعلهم

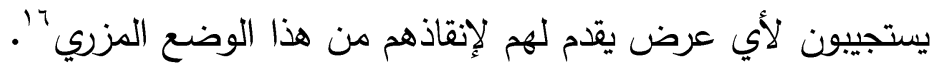
ع- عدم الوعي وقلة الخبرة لبعض الأفراد:

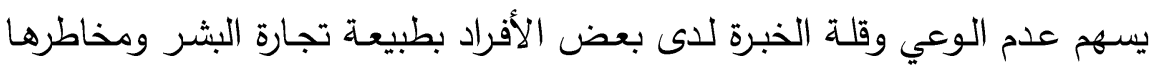

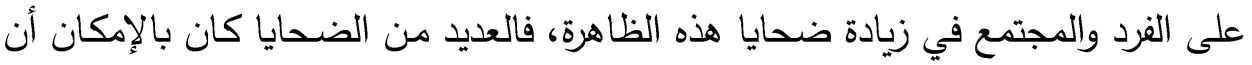

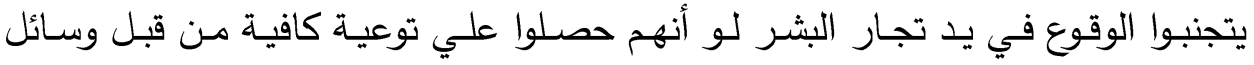
الإعلام ومنظمات المجتمع المدني. فبعض ضـايا جرائم الاتجار بالبشر خاصـة السخرة او العمل القسري للعمال وخدم المنازل يجهلون بحقيقة أن ما يقومون به من أعمال تمثل بالئل

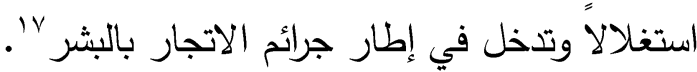
ه- ضعف الرقابة على أصحاب الأعمال:

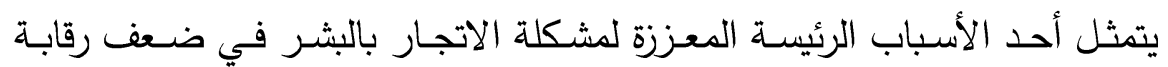

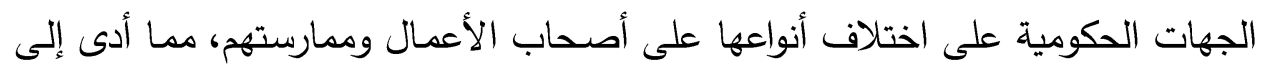
توسيع كثير من رجال الأعمال نطاق تجارتهم لتشمل الاتجار بالبثر ، حيث يقوم التجار

17 ذياب موسى ورافع عارف الخريشة البدانية، الاتجار بالبشر : الأسباب والعواقب، المجلة العربية للاراسات الأمنية، جامعة نايف

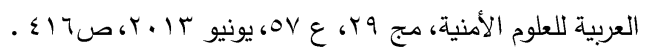

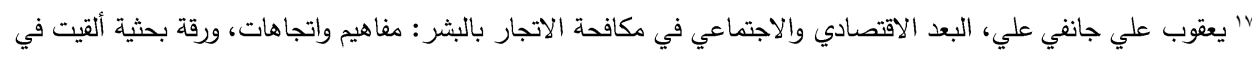

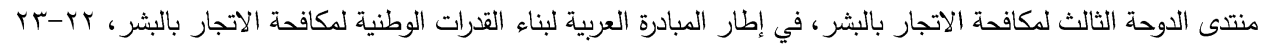

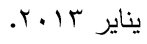

العدد السادس والعشرون (الجزء الثالن) • r. F

مجلة بجلة كلية التربية- جامعة عين شثس 
الاتجار بالنساء العاملات في الخدمة المنزلية الأسباب وسبل المواجهة: دراسة حالة بمحافظة القاهرة

بالإعلان عن رغبتهم في التعاقد مـع أشخاص للعمل في مختلف المجالات، وفي مقابل أجور خيالية, ومن ثم يصطدم هؤلاء الأشخاص بالواقع، وغئه وهو أنهم ما كانوا سوى فريسة سهلة سقطت في شبالك تاجر خادع، ومن ثم يعيشون الواقع الأليم القاسي عندما يجدون

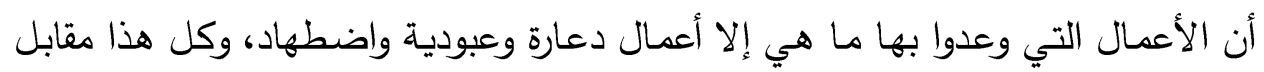

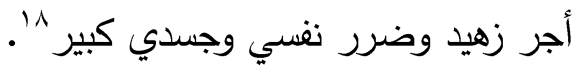

ومع انتشار ظاهرة عاملات المنازل في المجتمع، وتعرضهن لكثير من الانتهاكات

ومختلف أشكال الإساءة والاستغلال التي تتدرج ضمن إطار جرائم الاتجار بالبشر، يمكن رصد أهم الآثار والتداعيات السلبية المترتبة عليها في مختلف المجالات وذلك على النحو التالي:

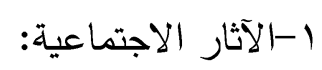

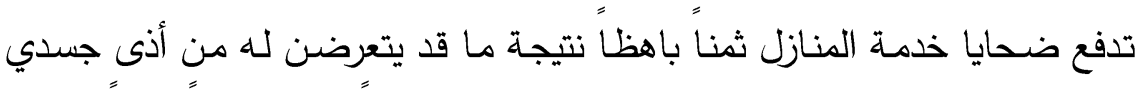

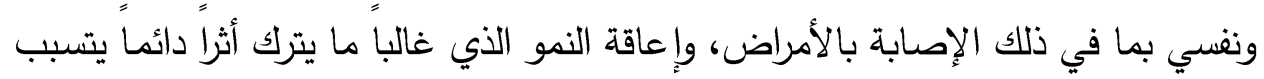

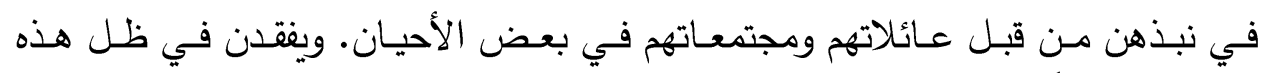

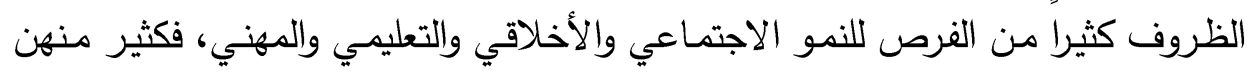

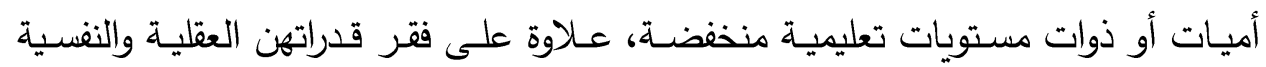
لحرمانهن من فرص النمو والارتقاء 19. كما يؤدي الاتجار بالنساء العاملات في الخدمة المنزلية إلى التثكك الاجتماعي.

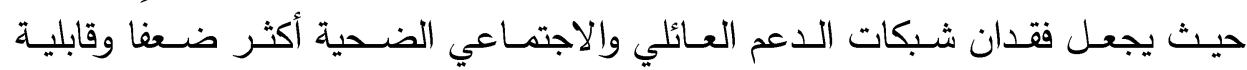
للانصياع لتهديدات صاحب العمل وطلباتهم، ويساهم ذلك بطرق مختلفة في تدمير البنى

^" حامد سيد محمد، الاتجار في البشر كجريمة منظمة عابرة للحدود بين الأسباب والتداعيات، الرؤى الاستراتيجية، مرجع سابق،

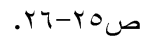

${ }^{19}$ Bridget Anderson, Just another job? Paying for domestic work. Gender and Development, 9 (1), 25-33, 2001.

العدد السادس والعشرون (الجزء الثان) •.r.

مجلة ججلة كلية التربية- جامعة عين شثس 
د/ هبه الله مصطفى محمد مصطفى

الاجتماعية، حيث يعيق انتقال القيم الثقافية والعلم من الأهل إلى الطفل ومن جيل إلى

آخر، ما يؤدي إلى إضعاف عمود رئيسي من أعمدة المجتمع ‘.

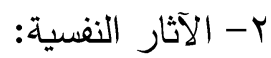

ينجم عن إسـاءة معاملة العاملات في الخدمة المنزلية واستغلالهن بعض الآثار النفسية، حيث يثعر بعضهن بالخجل وتدني مستوى تقدير الذات، بل إن بعضهن يثعر

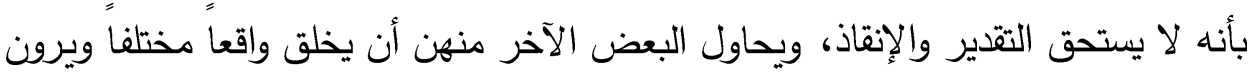
أن استمرارهن في تحمل سوء معاملة صاحب العمل واستخلالكن من أجل مساعدة أسرهم

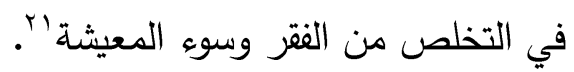
وقد تتتشـر ظـاهرة الانتحسار بين النسـاء العـاملات في الخدمـة المنزليـة بسبب الاستياء الثـديد ممـا يتعرضـون لـه مـن إهانـة ومذلـة تفقدهن الرغبـة في مواصلـة مسيرة حياتهن هروبا من الواقع المرير أو بسبب عدم تتبل المجتمعات لهن حتى بعد إنتهاء فترة

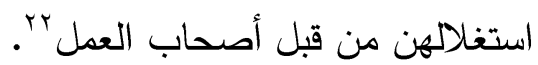

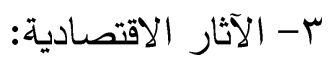

تتمثل في إكراه عاملات المنازل على القيام بأعمال شاقة نظير أجر زهيد بمعنى العى

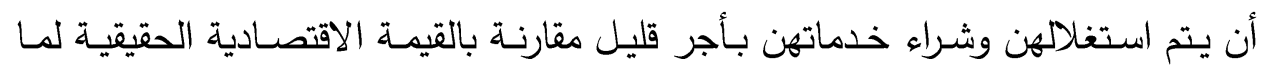

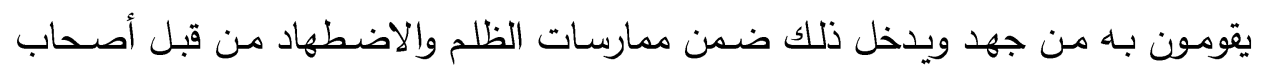

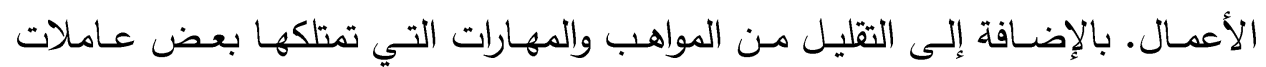

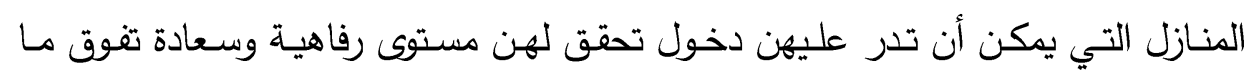
يحصلون عليه إذا ما تم توظيفها في مجالاتها الصحيحة, حيث ينتقص من قديمة العمل

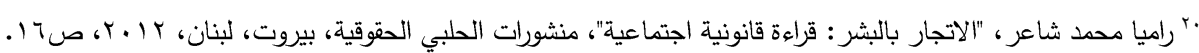

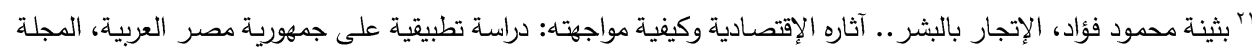

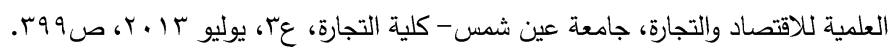

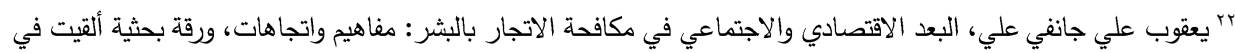
منتىى الدوحة الثالث لمكافحة الاتجار بالبشر ، مرجع سابق.

العدد السادس والعشرون (الجزء الثالن) • r. F (213) مجلة مجلة كلية التربية- جامعة عين شمس 
الاتجار بالنساء العاملات في الخدمة المنزلية الأسباب وسبل المواجهة: دراسة حالة بمحافظة القاهرة

المنزلي إذ ينظر إلى المهارات والكفاءات المصاحبة لـه على أنها قدرات فطريـة تتصف بها المرأة أكثر منها قدرات مكتسبة. وتؤدي انتشار ظاهرة العمالة المنزلية إلى تثويه هيكل العمالة والحرمان من القوى

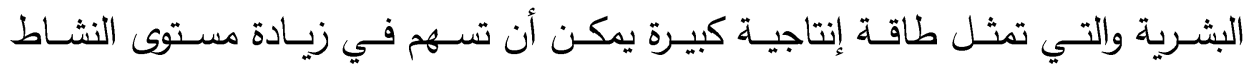

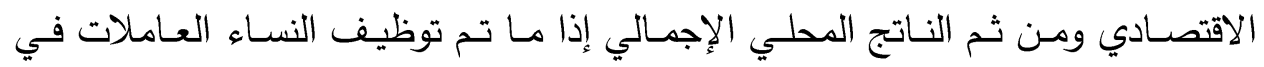
الخدمة المنزلية في أنثطة إنتاجية أخرى. وعلاوة على ذلك، فإن العمالة المنزلية تزيد من

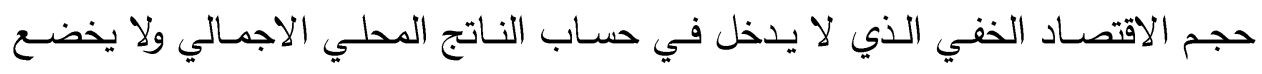
لقوانين وتثريعات الدولة مما يؤدي إلى فثل العديد من السياسات الاقتصادية التي تهدف إلى تحقيق الاستقرار الاقتصـادي ومـن ثم تكون عرضـة لظهور التضـخ وتدهور سعر الصـرف والعجز في ميزان المدفوعات وتثويه الوعاء الضـريبي الظـاهر والخفي وإهدار

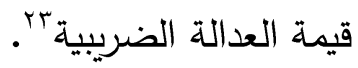
r r إشكالية الاراسة:

يمثل الاتجار بالبشر أبرز الآفات التي يتعرض لها العـالم بشكل عـام والبلدان

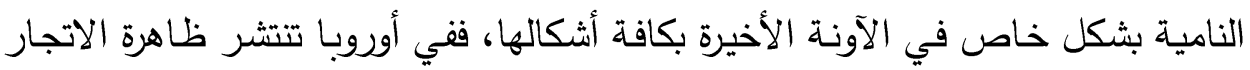
بالنساء والأطفال بشكل لافت للنظر، فبعد انهيار الاتحاد السوفيتي وتفككه إلى دويلات

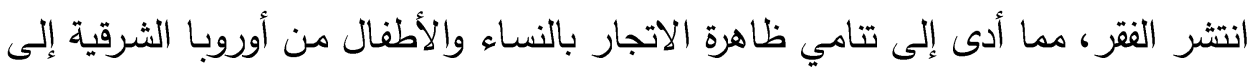

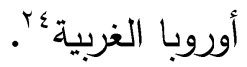

rrr مكتب العمل الدولي، العمل النلائق للعمال المنزليين، مرجع سابق، ص ع. انظر في ذلك أيضا:

يعقوب علي جانفي علي، البعد الاقتصادي والاجتماعي في مكافحة الاتجار بالبشر : مفاهيم واتجاهات، ورقة بحثية ألقيت في

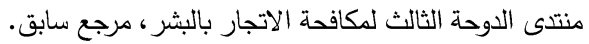
بثينة محمود فؤاد، الإتجار بالبشر .. آثاره الإقتصادية وكيفية مواجهته: دراسة تطبيقية على جمهورية مصر العربية، مرجع سابق،

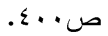

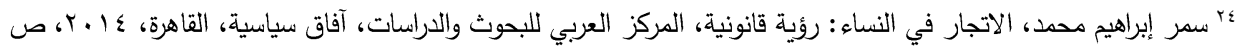


وتحتل جريمـة الاتجـار بالبشر المرتبـة الثالثة على مستوى أكثر الجرائم ربحا بعد

تجـارة المخـدرات والسـلاح، حيـث يحصـــ مـن وراءهـا بـلايـين الـدولارات سـنوياه ب. فقـد أصبحت التجارة الأكثر ربحا حيث يعيش حوالي rV مليون نسمة في العالم سنوياً تحت ظل العبودية الحديثة أو مـا يعرف بتجارة البشر، ويتعرضون للمتاجرة بهم كسلع رخيصـة ليبلغ حجم الأرباح مـا يقرب من · 7 مليار دولار سنويا، وعلى المستوى العربي يوجد ما يقرب من r .0 مليون شخص يتعرضـن للإتجار والذي يحقق أربـاح تقدر بحوالي بr مليار دولار سنوياحا ب. وو فقا لاراسـة بعنوان التقديرات العالمية الخاصـة بالرق في العصر الحديث أجرتها منظمة العمل الدولية ومؤسسة Walk Free خلال عام 1 أ. ب، خلصت إلى أن أشكال الرق المعاصرة بلغت ب. . ع مليون نسمة، وشكلت النساء والفتيات أ في المائــة مدـن انتهكـت حقـوقهم الإنسـانية فـي عـام 1 ا ـ ب مـن جـراء أشـكال الــرق

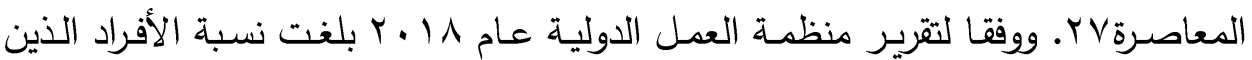
وقعوا تحـت وطنأة السـخرة والعمـل الجبري 9. ؟ مليون نسمة. وأن أكثر مسن يخضـن للسـخرة والعمـل الجبـري هـن النسـاء والفتيـات حيـث يشـكلن نسـبة سج فـي المائـة مـن الضـايا. وتتعدد أشكال الإجبار التي يعـاني منها الضـحايا تحت وطئة العمل الجبري

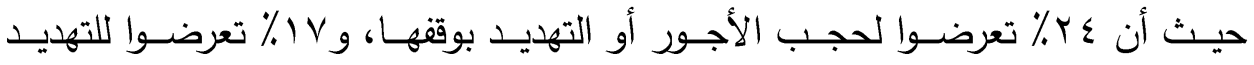

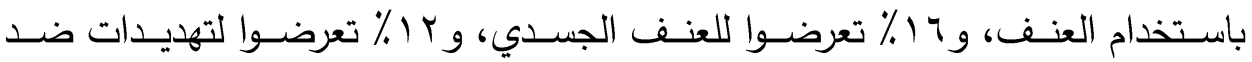

${ }^{25}$ Trafficking in Women and Children: The U.S and international Response. (May 10, 2000). P.1 Congressional Research service Report 98 - 649 C.

بr أميرة محمد بكر البحيري، الاتجار بالبشر وبخاصة الأطفال من وجهة النظر العلمية النفسية والاجتماعية والقانونية، دار

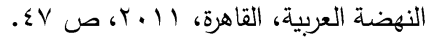
${ }^{27}$ International Labour Organization, Global estimates of modern slavery: Forced labour and forced marriage, Executive summary, Geneva, 2017, p.7-8.

28International Labour Office, Ending forced labour by 2030: a review of policies and programmes, Geneva: ILO, 2018, p. 3.

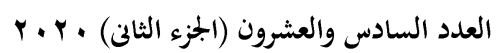


الاتجار بالنساء العاملات في الخدمة المنزلية الأسباب وسبل المواجهة: دراسة حالة بمحافظة القاهرة

ومـن ثم أصبحت ظـاهرة استغلال عـاملات المنـازل باعتبارهـا صـورة من صـور

الاتجار بالبشر تمثل أحد التحديات الخطيرة التي تواجهها الإنسـانية في القرن الحادي

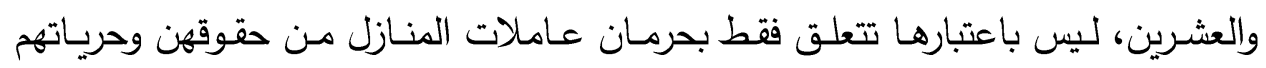

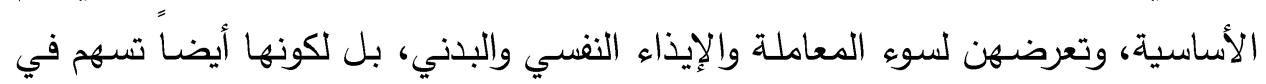
انتشار العنف والفساد وإعاقة التتمية وتهديد الصحة العامـة في مناطق عديدة من العالم. الأمر الذي يثير إثكالية الدراسـة والتي تدور حول التساؤل التالي: مـا هي التدابير التي

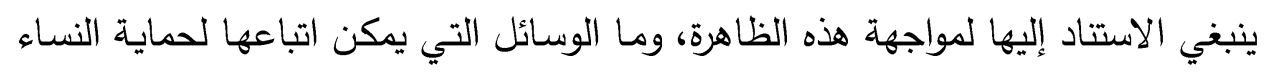

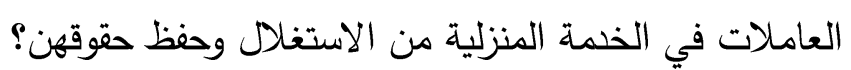

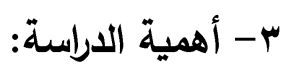
ا -تتبع أهمية هذه الدراسة من كونها تستهدف شريحة مهمة، حيث تعتبر العمالة المنزلية

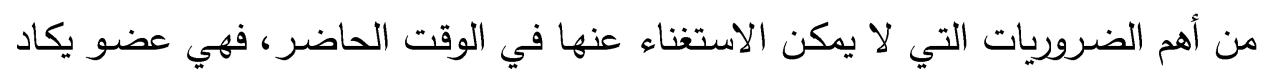

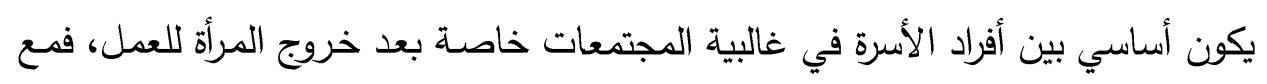

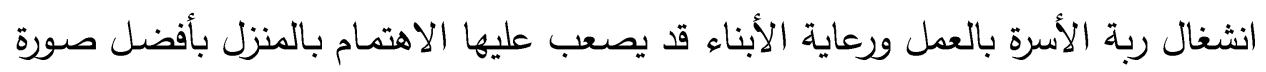

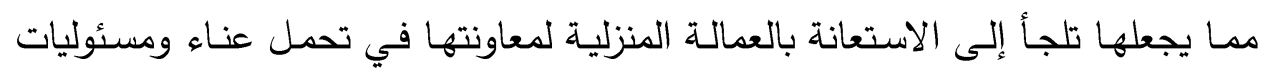
المنزل المتعددة.

r- يعتبر موضوع استغلال عاملات المنازل كصورة من صور الاتجار بالبشر ذو أهمية على الصعيدين المحلي والدولي، حيث يعد موضوع السـاعة من حيث انتشاره وتجاوزه

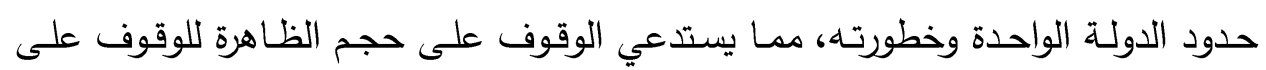
آثارها وكيفية مواجهتها.

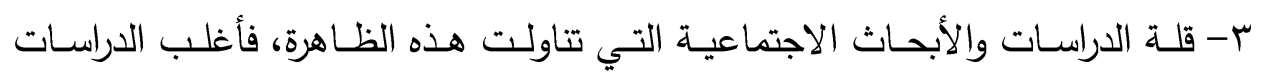
السابقة ركزت على جرائم الاتجار في البشر فقط بوجه عام.

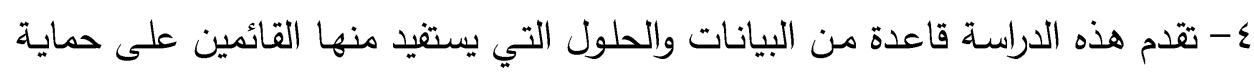

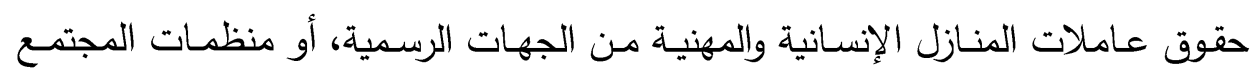
المدني. 
د/ هبه الله مصطفى محمد مصطفى

צ- - أهداف الدراسة:

تسعى الدراسة الراهنة إلى تحقيق جملة من الأهداف تتمثل فيما يلي:

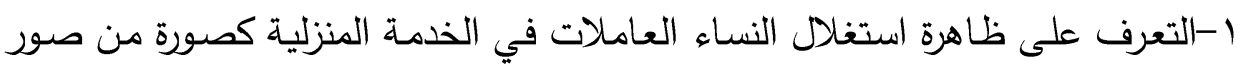
الاتجار بالبشر •

r- الوقوف على المبررات التي تجعل النساء العاملات في الخدمـة المنزلية تقع ضحية لجريمة الاتجار بالبشر . ب- تحديد مظـاهر الاسـاءة والاستغلال الذي تتعرض لـه النسـاء العـاملات في الخدمـة المنزلية. ع - بحث أساليب مواجهة ظاهرة الاتجار بالنساء العاملات في الخدمة المنزلية.

$$
\text { ه- تساؤلات الاراسة: }
$$

$$
\text { ا-ما مفهوم الاتجار بالبشر وما أبرز صوره؟ }
$$

r- ما الأسباب التي تدفع عاملات المنازل لتحمل الإساءة والاستغلال الواقع عليهن من صاحب العمل؟ مان

ب- مـا مظـاهر الإسـاءة والاسـتغلال التي تتعـرض لهـا النسـاء العـاملات في الخدمـة

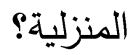
ع - مـا الإجراءات الوقائيـة المقترحـة لحمايـة النسـاء العـاملات في الخدمـة المنزليـة مـن

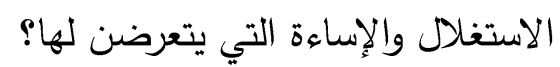

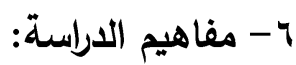

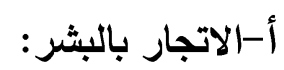
يقصد بالاتجار بالبشر بأنـه " جميع التصرفات المشروعة وغير المشروعة، التي تحيل الإنسان إلى مجرد سلعة أو ضحية يتم التصرف فيها من خلال وسطاء محترفين عبر الحدود الوطنية بقصد استغلاله في أعمال ذات أجر متدن أو في أعمال جنسية أو فئ

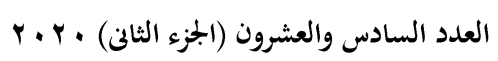
(217) مجلة بجلة كلية التربية- جامعة عين شثس 
الاتجار بالنساء العاملات في الخدمة المنزلية الأسباب وسبل المواجهة: دراسة حالة بمحافظة القاهرة

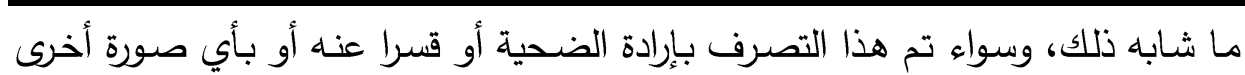

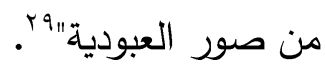
ووفقـا للمـادة الثالثـة مـن بروتوكـول الأمــم المتحـدة لمنـع وقــع ومعاقبـة الاتجـار بالأشخاص، وخاصة النساء والأطفال يعرف الاتجار بالأشخاص بأنه "تجنيد أشخاص أو وتو نقلهم أو إيواؤهم أو استقبالهم بواسطة التهديد بالقوة أو استعمالها أو غير ذلك من أشكال بالهال

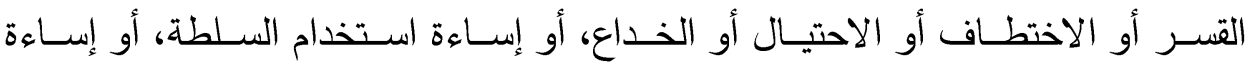
استغلال حالة استضعاف أو بإعطاء أو تلقي مبالغ مالية أو مزايا لنيل موافقة شخص لاءوله الها

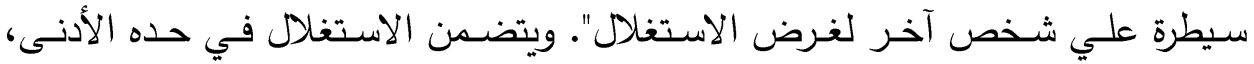

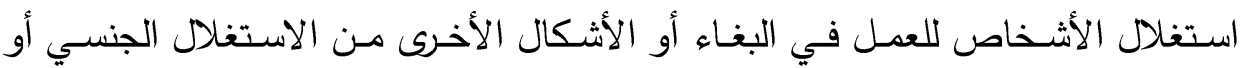

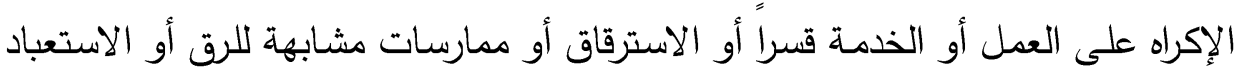

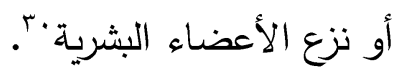
ومن خلال التعريف الوارد في بروتوكول منع الاتجار بالبشر ، يتضح أن الاتجار بالبشر يتكون من ثلاثة عناصر وهي:

أولا- الأفعال: ويقصد بها تجنيد الأشخاص أو نقلهم أو إيوائهم أو استقبالهم.

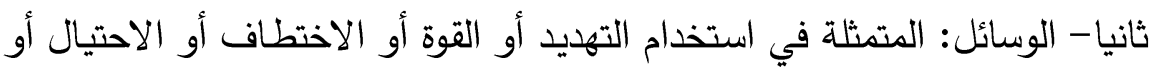
الخداع أو إساءة استعمال السلطة أو تلقي مبالغ مالية.

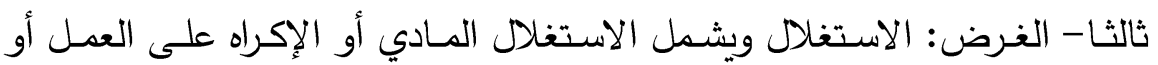

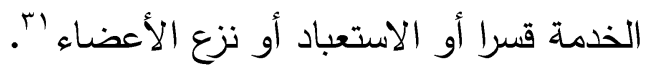

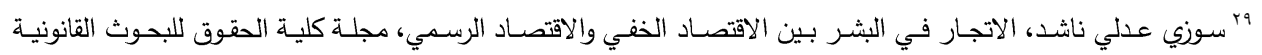

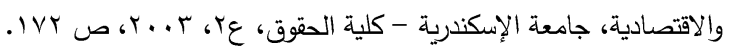

${ }^{30}$ Elaine Pearson, Human Rights and Trafficking in Persons: A Handbook, Bangkok, Global Alliance Against Traffic in Women (GAATW), 2000, P.21.

"r حامد سيد محمد حامد، الاتجار في البشر كجريمة هنظمة عابرة للحدود بين الأسباب والتداعيات، الرؤى الاستراتيجية، المركز

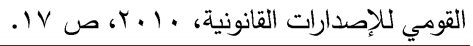

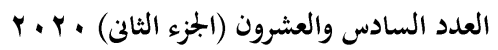

مجلة بجلة كلية التربية- جامعة عين شثس 


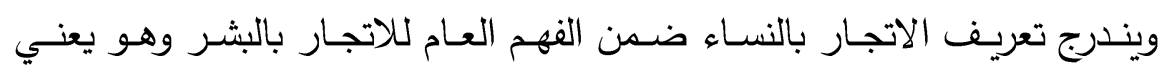
"الاستخدام والنقل والإخفاء والتسليم للأشخاص من خلال التهديد أو الاختطاف، واستخدام

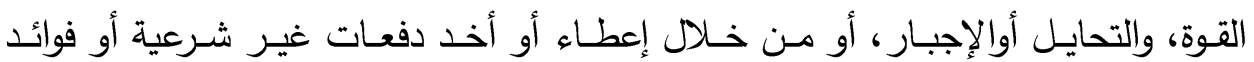

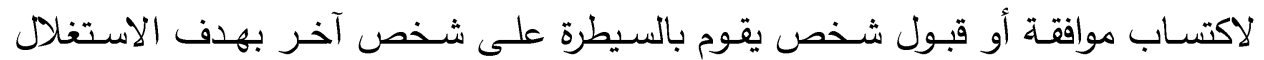

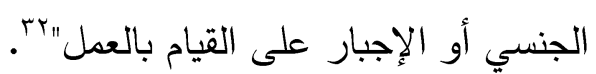
ويعد الاتجار بالبشر عموماً وبالنساء على وجها الخصوص الخدار انتهاكاً لحقوق الإنسان

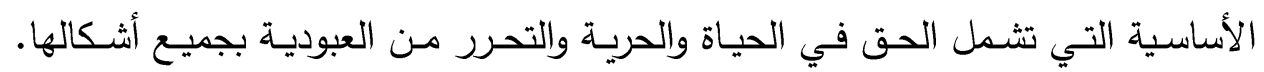
وتتعدد صـور ومظـاهر الاتجـار بالنسـاء، حيث لا يمكن حصـرها وذلك بسبب التطور التثني والتقدم العلمي، اللذان يفرزان العديد من صور ومظاهر الاتجار والاستغلال، غير

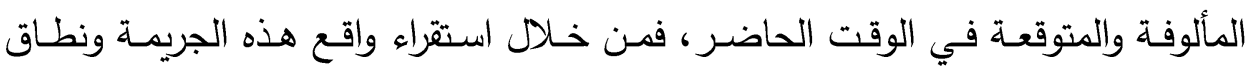

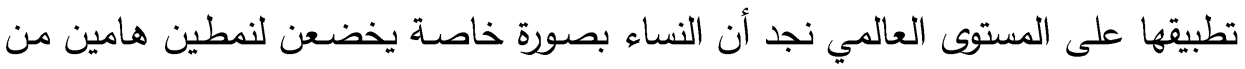

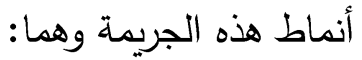
• الاتجـار بالنسـاء لغرض الاستغلال الجنسي: حيث يتم الإجبار على ممارسـة الجنس التجاري بالقوة والخداع والإكراه.

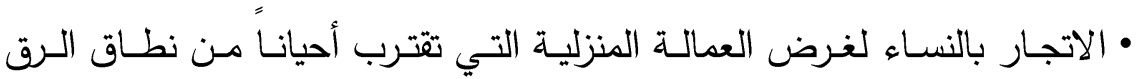

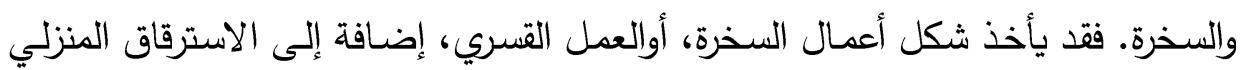
اللاإرادي والمعروف بالعبودية المنزلية التي يقع ضحيتها خدم المنازل من خلال استخدام

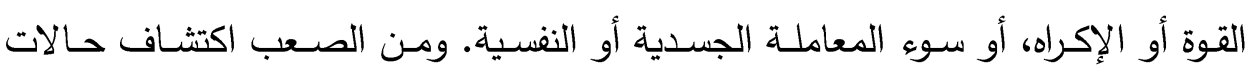

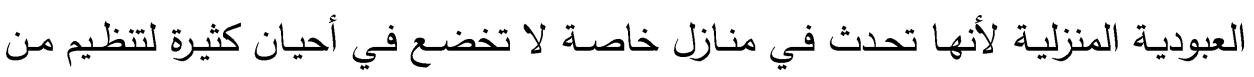


الاتجار بالنساء العاملات في الخدمة المنزلية الأسباب وسبل المواجهة: دراسة حالة بمحافظة القاهرة جانِ السلطات العامة. وقد يكون وضـع خادمات المنازل هي أكثر صور هذا الاتجار نمواً وانتشاراً وبناء على ذلك يمكن تحديد التعريف الاجرائي للفهوم الاتجار بالنساء في هذه الدراسة فيما يلي: تئي

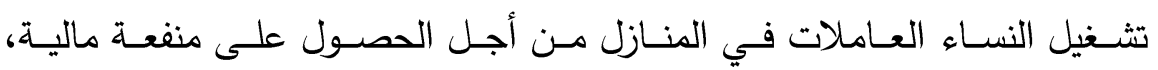

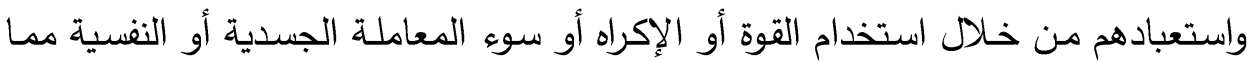
يثكل خطرا على حياتهم وسلامتهم وذلك بسبب المعاملة اللاإنسانية أو المهينة. ب- العاملات في الخدمة المنزلية: هن النساء اللاتي يقمن بأعمال منزلية نظير أجر، ووفقاً للتصنيف الدولي الموحد

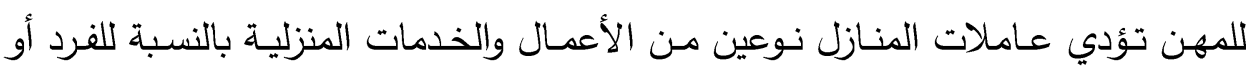
الأسرة هما:

أ-التدبير المنزلـي ويتضـمن أعمـالاً مثل: نظافـة المنزل وإعداد الطعـام وغسل

الملابس.

ب- الرعايــة الشخصـية وتتضــــن تقـــيم الرعايــة للأطفــال والمسـنين و ذوي

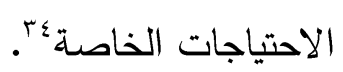
وعلى الرغم مـن وجود التشـريعات التي تحمي عـاملات المنـازل في العديد مـن البلدان، إلا أنها غيـر مطبقـة على نطـاق واسـع، حيـث يتم استغلال عـاملات المنـازل واستخدامهن بصورة مخالفة لأحكام القانون ومخالفة للإنسانية بما يعتبر صورة من صور

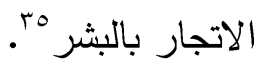

rrأمل الدبيات، مشاكل الاتجار بالنساء في العالم العربي، الأكاديمية السورية الدولية: بحث مقدم لنيل درجة الدبلوم في الثؤون

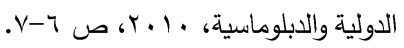

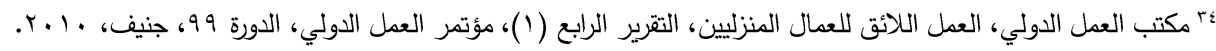

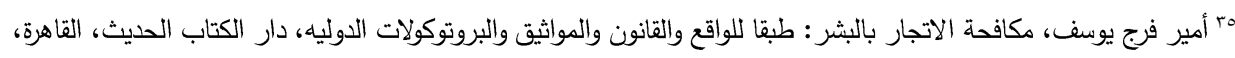
. $r \leqslant ص$ ص. II

r.r. العدد السادس والعشرون (الجزء الثالن)

مجلة بجلة كلية التربية- جامعة عين شثس 
وبنـاء على ذلك يمكن تحديد التعريـف الاجرائي لمفهوم العـاملات في الخدمـة المنزلية في هذه الدراسة فيما يلي:

هن النسـاء اللآتي تعملن على خدمـة الغير مقابـل الحصـول على أجر ، ويقهـن بمجموعة متتوعة من الخدمات المنزلية للفرد أو الأسرة من توفير الرعاية للأطفال والكبار

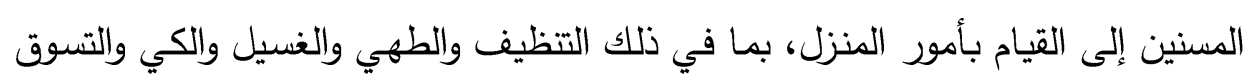

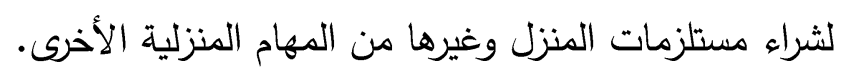

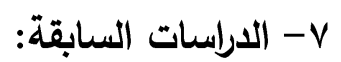

نستعرض في هذا المحور بعضاً من التراث البحثي الإمبريقي الذي تتاول ظاهرة

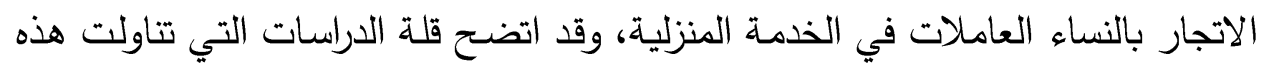

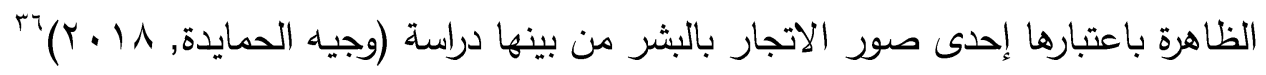

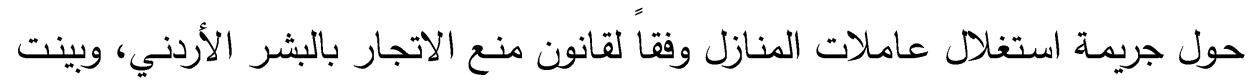

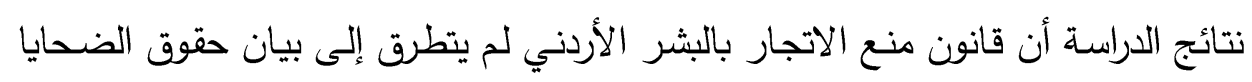

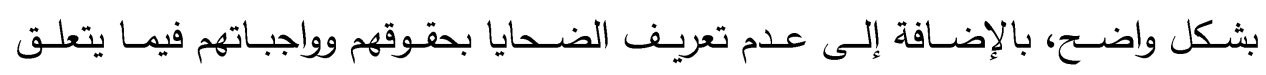

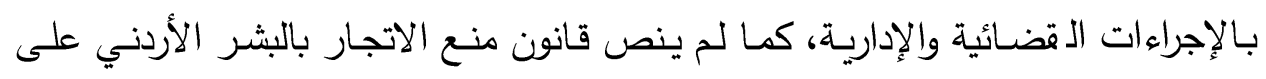
تجريم الشروع والاشتراك الجرمي في جريمة استغلال عاملات المنازل، وإنما ترك ذلك إلى لى لإنى القواعد العامة.

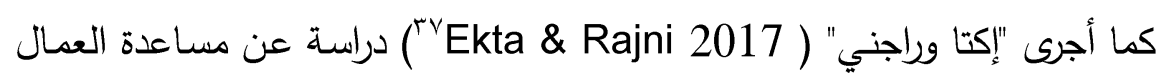
المنزليين والعوامل المؤثرة في إعمال حقوقهم في ولايـة البنجـاب، وقد تبـين أن النسـاء

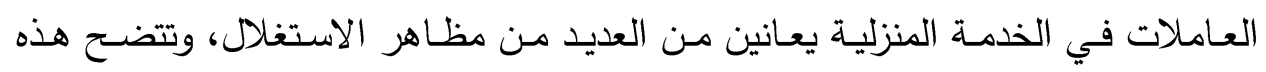

بr وجيه محمد الحمايدة، جريمة استغلال عاملات المنازل وفقاً لقانون منع الاتجار بالبشر الأردني والمعاهدات والمواثيق الدولية،

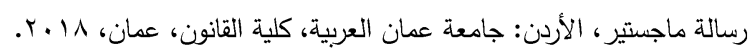

${ }^{37}$ Ekta Rani \& Rajni Saluja. (2017, October). A Study on Domestic Help Workers and Factors Affecting Realisation of their Rights in the State of Punjab, Jurnal of General Management Research, Vol.4, Issue 2, pp. 16-26.

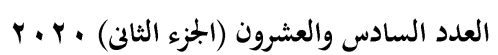

مجلة مجلة كلية التربية- جامعة عين شثس 
الاتجار بالنساء العاملات في الخدمة المنزلية الأسباب وسبل المواجهة: دراسة حالة بمحافظة القاهرة

المصـاعب في عدم الحصـول على الأجر المناسب، وضـعف القدرة التفاوضية، وعدم وجود حماية تشريعية، وعدم كفاية تدابير الرعاية الاجتماعية مع عدم وجود إجازة أسبوعية وإجازة الأمومة والاستحقاقات الصحية.

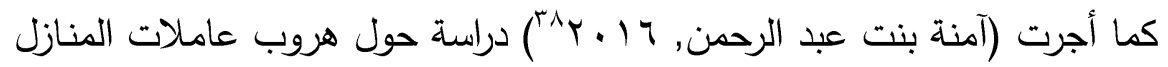
في منطقـة الريـاض بالمملكـة العربيـة، وتهدف الدراسـة إلى معالجـة الآثار الاقتصـادية المترتبة على هروب العاملة المنزلية، من خلال النظر إلى الأسباب والتعرف على الآثار الاقتصـادية المترتبـة على هروبها، وكيفيـة معالجتها. وتوصلت الدراسـة إلى عدة نتـائج أبرزها وجود علاقة وثيقة بين ظاهرة هروب عاملات المنازل وإجحاف حقوقهن المادية

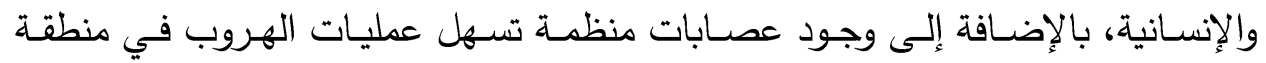
الرياض، ويعد وجود أنظمة مطبقة على أرض الواقع تحفظ حق العاملة وصـاحب العمل من أهم الحلول للقضاء على هذه الظاهرة.

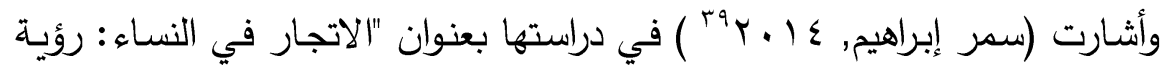
قانونيـة" إلى أن ظـاهرة الاتجـار بالنسـاء تجـاوزت قدرات الحكومـات والمنظمـات الدوليـة،

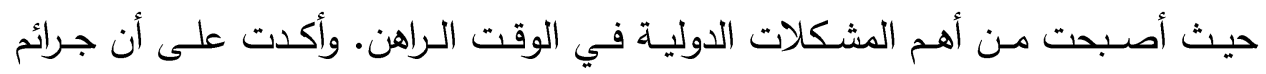

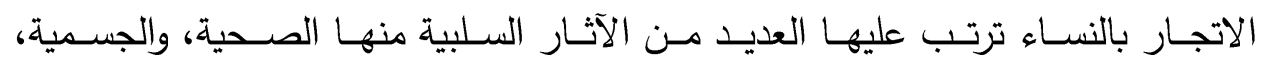

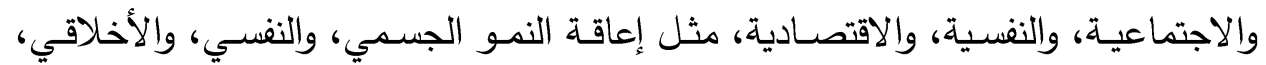

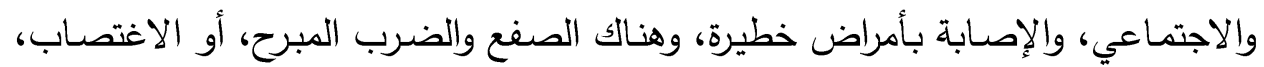

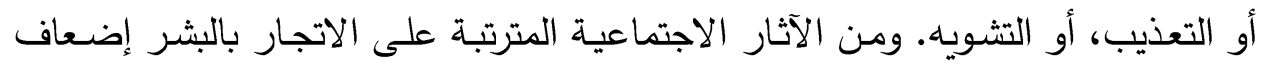
السلطة الحكومية فتصبح بعض الحكومات غير قادرة على حماية النساء.

^r أمنة بنت عبدالرحمن علي الأصقه، هروب عاملات المنازل في منطقة الرياض بالمملكة العربية السعودية: دراسة في الجغرافيا

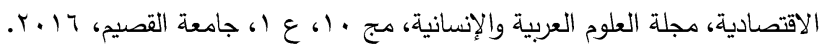

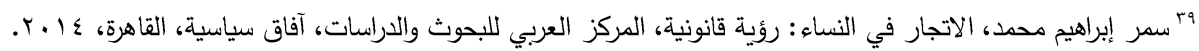

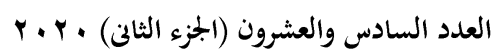


د/ هبه الله مصطفى محمد مصطفى

كما أكدت دراسة "دوبنر وتابرت" ( 2010 Dobner \& Tappert

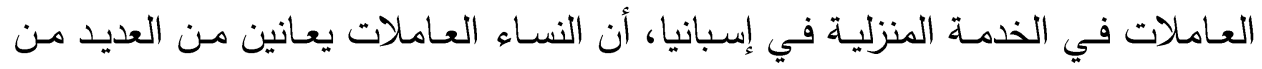
المشكلات أهمها مكان الإقامة وانخفاض الراتب وزيادة ساعات العمل دون الحصول على لى

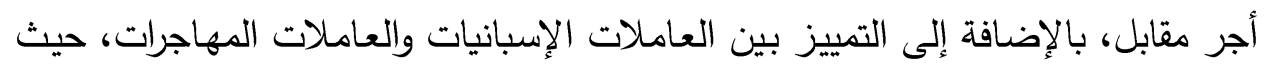
يفضل أصحاب العمل الخادمات المهاجرات بدرجة أكبر من الخادمات الإسبانيات. الاراسة الحالية على خربطة الاراسات السابقة: على الـرغم مـن اسـتفادت الدراسـة الراهنـة مـن الدراسـات السـابقة على المستوى

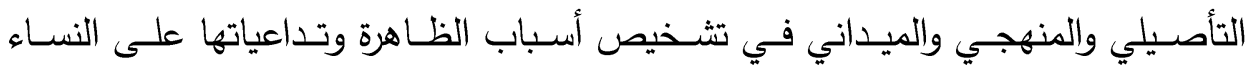
العاملات في الخدمة المنزلية، ولأن مشكلة العمل في الخدمة المنزلية تعتبر مشكلة مركبة يختلط فيها البعد الاجتماعي بما هو اقتصـادي وقانوني، لذا فإنه لابد من محاولة إيجاد حلول لمواجهـة ظـاهرة الاتجار بالنسـاء العـاملات في الخدمـة المنزلية مـن خـلال إجراء دراسة اجتماعية تستهدف فهم هذه الظاهرة، وأسباب تفاقمها والآثار المترتبة عليها. ^- الإطار النظري المفسر لموضوع الدراسة: تفسير ظاهرة الاتجار بالنساء العاملات في الخدمة المنزلية واستغلالهن في ضوره التثيؤ وسلعنة الإنسان: يعد الفيلسوف جورج لوكاتش أول من بحث في موضوع التشيؤ في الفكر الفلسفي الماركسي المعاصر ، في كتابه الهام التاريخ والوعي الطبقي، الذي قدم فيه تحليل للتشيؤ في ضوء دراسته النقدية لوضع الإنسان في المجتمعات المتقدمة تكنولوجيا في ظل التحكم الشـامل للعقل الأداتي على مختلف مناحي الحياة الإنسانية، الذي أدى إلى تشيؤ كلي أصبح يعيشـه الإنسـان الم عاصر في شتى ميادين الحياة الإنسانية؛ على مستوى النظام الاجتماعي والحياة الاقتصادية والثقافة والحضارة.

${ }^{40}$ Dobner, M., \& Tappert, S. (2010, September). Female migrant domestic workers and their Spanish employers in times of crisis. A comparative analysis of consequences for women on both sides of the coin. In Paper for the SGIR 7th Pan-European International Relations Conference, Stockholm, Sweden (pp. 9-11).

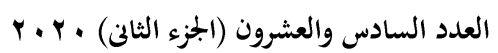

مجلة مجلة كلية التربية- جامعة عين شثس 
الاتجار بالنساء العاملات في الخدمة المنزلية الأسباب وسبل المواجهة: دراسة حالة بححافظة القاهرة

قـدم لوكـاتش مفهـوم التثـئو باعتبـاره مفهومــا اقتصـــاديا يـرتبط بتحليـل البنيـة

الاقتصـادية والصـلات التجاريـة في المجتمع الرأسمالي المعاصـر ـ فقد استتـد في تحليله

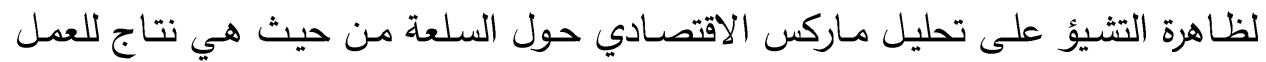

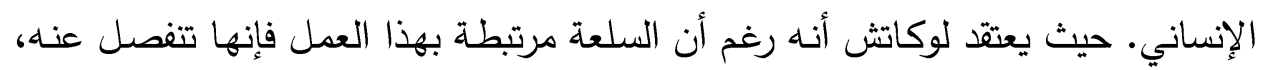
بحيث يبدو العمل في آخر المطاف في صورة شيء جامد ومستقل عن العالم الإنساني.

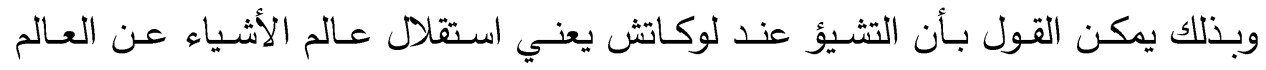
الإنساني الذي تتتج فيه هذه الأشياء نفسها. بحيث تنفصل هذه الأشياء عن الإنسان،

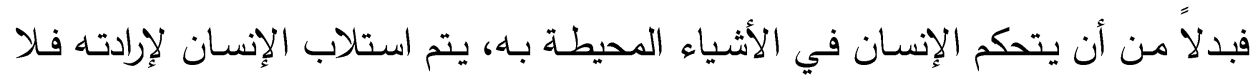

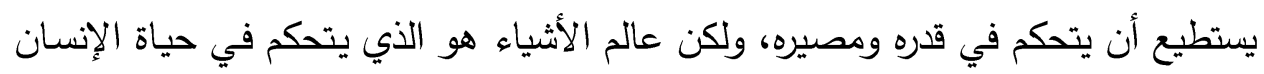

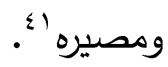

وهـذا يعنـي أن التشـيؤ يحـول العلاقـات الإنسـانية - فـي ظـل هيمنـة النظــام

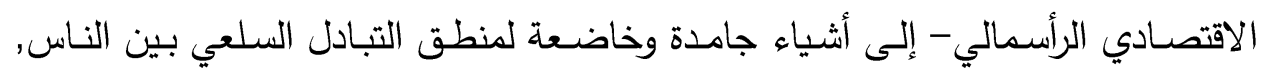

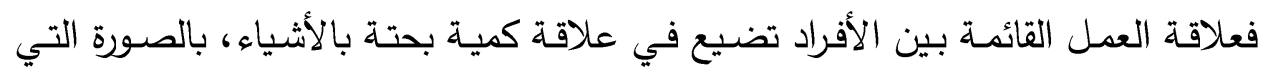
تدول فيها البشر إلى سلع أو بضائع، بحيث يخضعون لقوى وأثياء خارجة عن إرادتهم. وهكذا تتحول العلاقات الإنسانية القائمة بين الناس إلى علاقات بلى بتحصر في أشياء، وفي

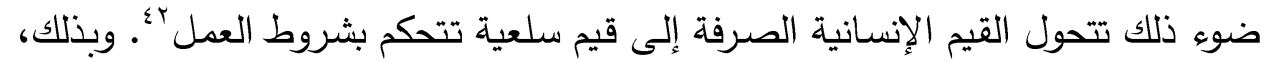

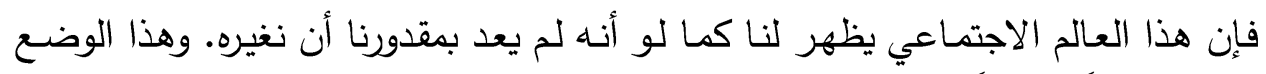

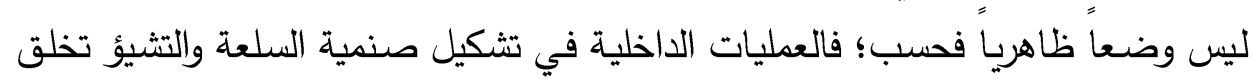

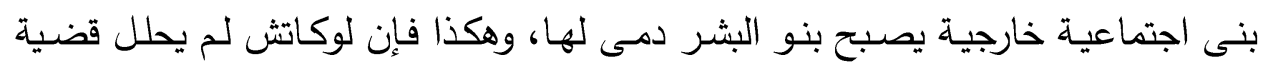

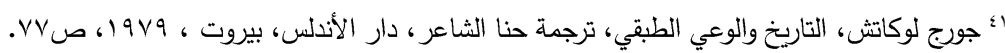

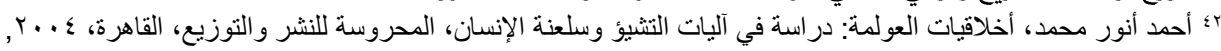

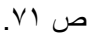
انظر في ذلك أيضا: رمضان بسطاويسي، علم الجمال عند لوكاتش، الهيئة المصرية العامة للكتاب، القاهرة، الو99، صVVV.VA

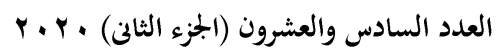

مجلة مجلة كلية التربية- جامعة عين شمس 
التشيؤ من الناحية الاقتصادية فحسب وإنما يركز على البعد الإنساني والعلاقة القائكة بين

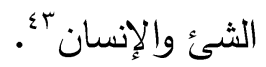

وقد اهتم أكسل هونيث، في السنوات القليلـة الأخيرة، بتجـاوز التفسير الأحسادي

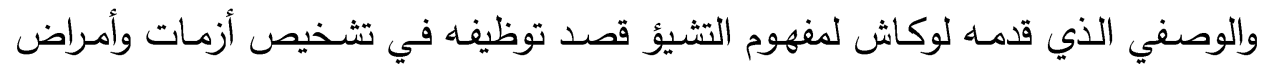

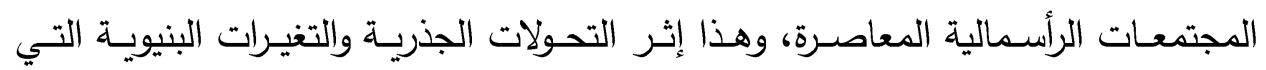

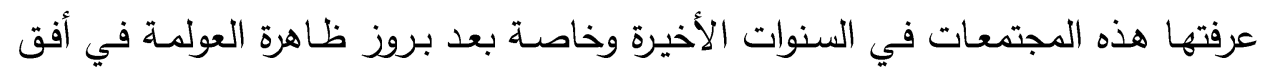

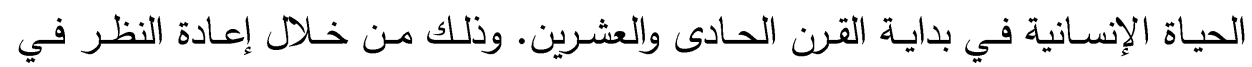
الطابع الميكانيكي للعلاقة الموجودة بين القاعدة المادية أو الاقتصادية ( البنية التحتيـة)

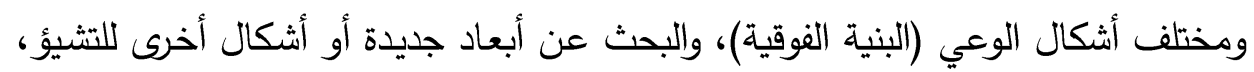

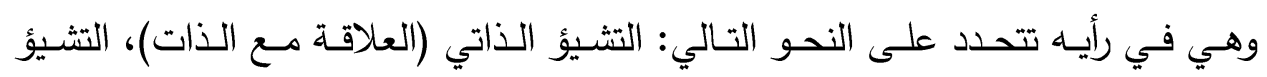
الموضوعي (العلاقة مع العالم)، التشيؤ التذاوتي (العلاقة مع الآخرين)، وهذا ضمن رؤى

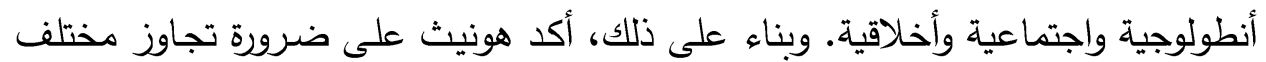

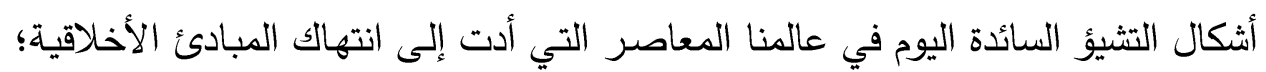

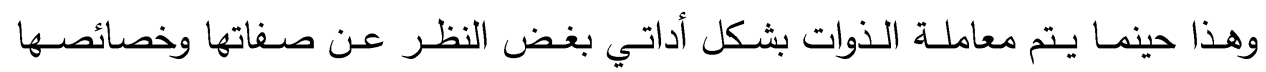

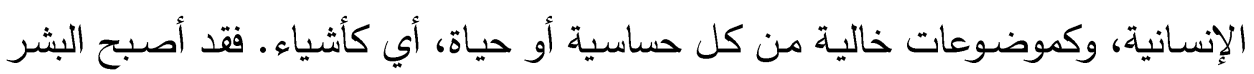
في ظل التشيؤ يعاملون كموضوعات ميتة وخالية من كل إحساس وعاطفة وصورة غير الإن إنسانية ؛ ؛

وبناء على ذلك نستطيع صياغة إطاراً تفسيرياً لظاهرة الاتجار بالنساء العاملات في الخدمة المنزلية يدور حول تثيؤ المرأة وسلعنتها، فقد تحول نظام العمل في الخدمة

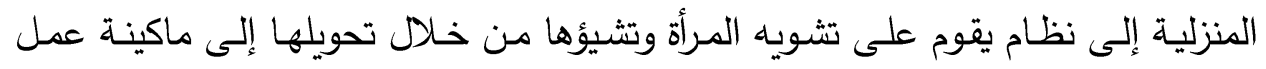
rأ إيان كريب، النظرية الاجتماعية، من بارسونز إلى هابرماس، ترجمة محمد حسن غلوم، العدد ؟ ؟ب، سلسلة عالم المعرفة، الكويت، 999

${ }^{44}$ Axel Honneth, La réification. Petit traité de théorie critique, traduit par Stéphane Haber, Paris: Gallimard, 2005, P.15-40.

r.r. . العدد السادس والعشرون (الجزء الثان) 
الاتجار بالنساء العاملات في الخدمة المنزلية الأسباب وسبل المواجهة: دراسة حالة بمحافظة القاهرة

فقط، وإقصاء أي بعد إنساني لها. ويتم ذلك من خلال إخضاع المرأة العاملة في الخدمة

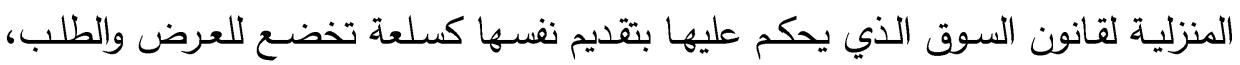
ومحاولة تثمين هذه السلعة بكافة الوسائل التي توفر لها قيمة تبادلية مقبولة، وتفريغها من أي قيم إنسانية من خلال استنزاف إنسانيتها التي يتم هدرها بدخولها إلى هذا السوق. ثانياً: الإجراءات المنهجية للدراسة: يطرح هذا المبحث لمنهجيـة الدراسـة الميدانيـة, والتي تستمد شـرعيتها بالأسـاس مـن الأطر النظرية وأهداف الدراسة, وذلك من خلال التالي:

ا-نوع الاراستة:

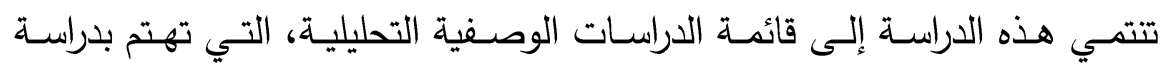

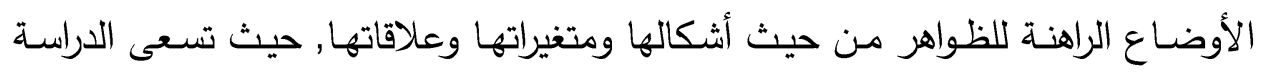
الحالية إلى وصف وتفسير ظاهرة الاتجار بالعاملات في الخدمة المنزلية، والآثار المترتبة عليها، بقصد محاولة الوصول إلى حلول لمواجهة هذه الظاهرة.

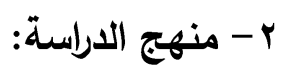

تعتمد الدراسـة على المنهـج الوصفي التحليلي ذي الطـابع الكيفي الذي يتضــن

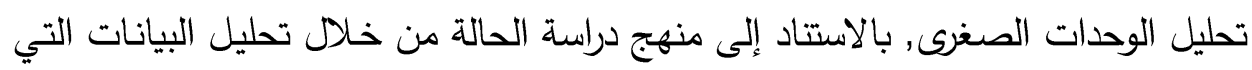
تم الحصول عليها من المقابلات الفرديـة المتعققة، بهدف التعرف على ظـاهرة الاتجار

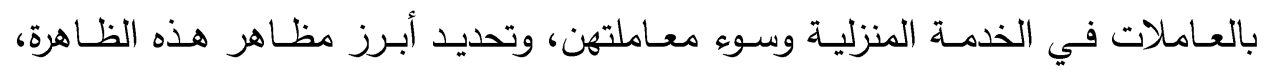

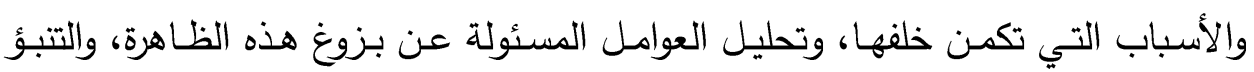
بأساليب مواجهة هذه الظاهرة. r- أدوات وأسلوب جمع البيانات:

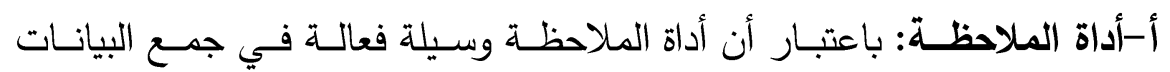
المساعدة في رصد الظاهرة، والأسباب التي تقف خلفها حيث الحالة العامة للمرأة العاملة العانة في الخدمة المنزلية، والدلالات الثكلية لها.

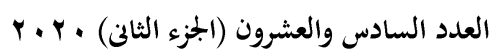

مجلة مجلة كلية التربية- جامعة عين شثس 
د/ هبه الله مصطفى محمد مصطفى

بــليـل مقابــة متعمقـة: فقد قامـت الباحثة بدراسـة متعمقـة لعدد مـن الحـالات

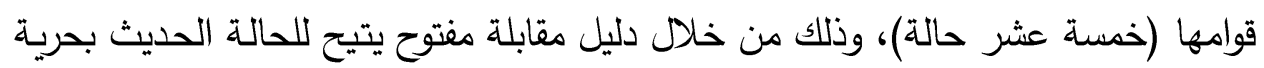
عن ما تتعرض له من إساءة معامله رب المنزل لها. وتكون الدليل مـن أربعـة محساور أساسية بالإضـافة إلى البيانـات الأساسية التي لهي

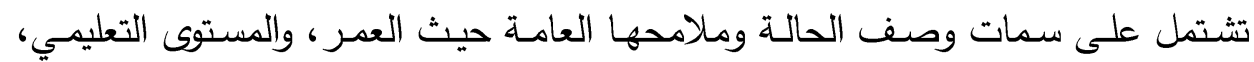
والدخل وإعالة الأسرة، ويركز المحور الأول على طبيعة العمل الذي تقوم به العاملات في

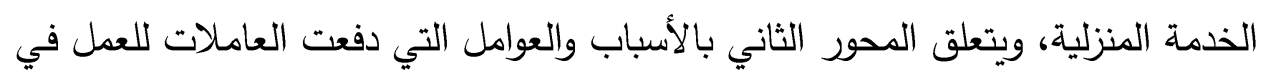

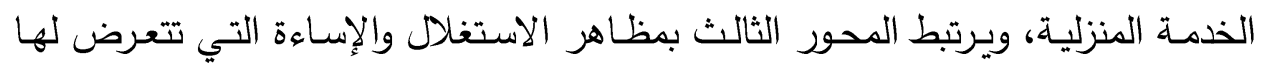
عاملات المنازل، وأخيراً تناول المحور الرابع الآثار الناجمة عن استغلال عاملات المنازل وإساءة معاملتهن من قبل رب العمل. وقد مر تصميم دليل المقابلة بعدة مراحل، تضمنت مرحلة الصياغة المبدئية في ضوه أهداف الدراسة، ثم مرحلة التحكيم، ثم تعديل صياغة بعض البنود غير الواضحة بعد التحكيم وإضـافة بنود وحذف أخرى، ثم تجريب الدليل للتأكد من صـاحلاحيته، وأخيراً التطبيق الفعلي. ج-الإخباريون: حيث استعانت الباحثة بالإخبارين، وهو صـاحب مكتب تشغيل

العمالة المنزلية. ؛ - مجالات الدراسة: وتنقسم إلى : الى أ-المجال البشري: أجريت الدراسة على 10 حالة من العاملات في الخدمة المنزلية، وصاحب مكتب تشغيل للعمالة المنزلية.

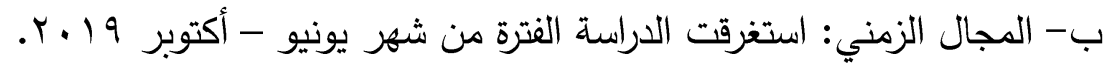
ج- المجال المكاني: تم إجراء الدراسة في محافظة القاهرة. 
الاتجار بالنساء العاملات في الخدمة المنزلية الأسباب وسبل المواجهة: دراسة حالة بحافظة القاهرة

ه- عينة الدراسة:

تضمنت عينة عمدية مكونة من 10 حالة من النساء العاملات في الخدمة المنزلية روعي في اختيارهن التتوع في السن, والمستوى التعليمي, والحالـة الاجتماعيـة, وكانت

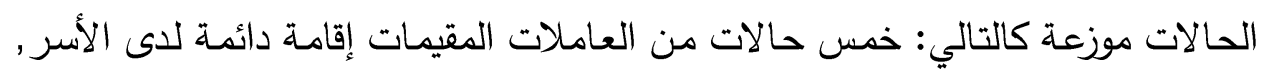

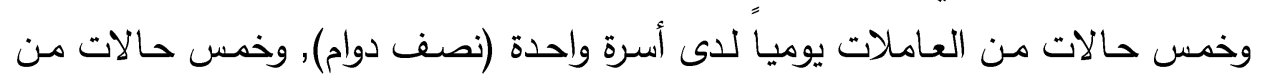
العاملات بالمرة لدى أسر متعددة. والإخباري (صاحب مكتب تشغيل للعمالة المنزلية). آ- سمات وصف الحالات وملامحها العامة:

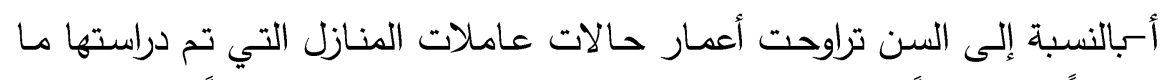

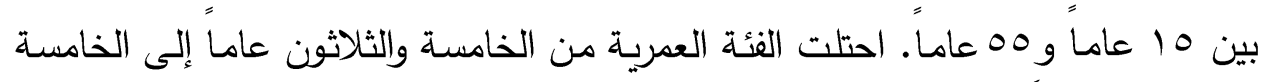

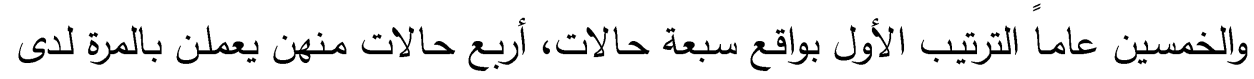
أسر مختلفة، وثلاث حالات عاملات باليومية لدى أسرة واحدة، ويدل ذلك على أنى أن هذه الته

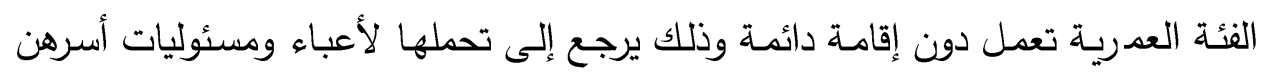

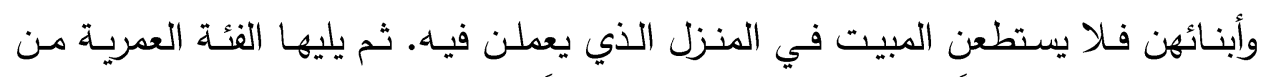

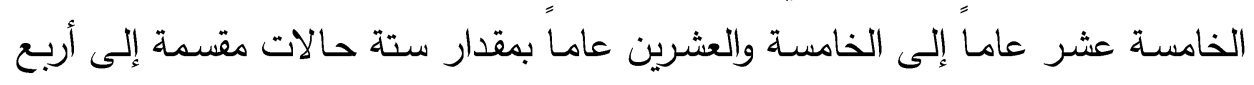
حالات مقيمات إقامة دائمة لدى الأسر التي يعملن لديها، وحالتين من العاملات باليومية

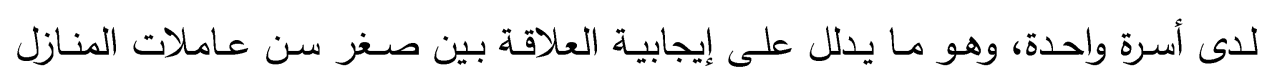

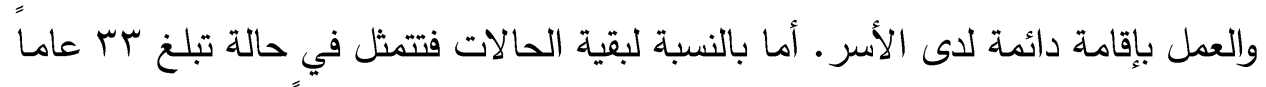

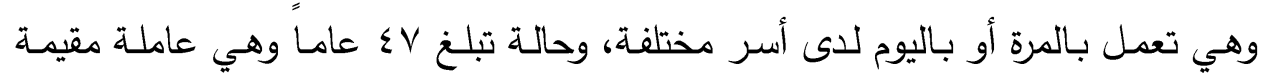
إقامة دائمة لدى الأسرة التي تعمل لديها. ب- بالنسبة للحالة الاجتماعية: احتلت فئة المتزوجات الصدارة بواقع تسع حالات، ثم يليها فئة الأعذب بواقع أربع حالات, ثم يليها حالتين أرملة.

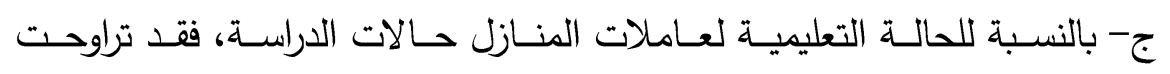
مستويات تعليمهن ما بين الأمية حتى التعليم المتوسط. فقد اتضح أن سبع حالات أميات،

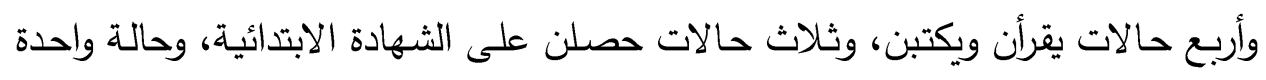


فقط حصلت على الثهادة الاعدادية. ويدل ذلك على تدني مستوى تعليمهن الذي يرجع إلى الفقر والضغوط الاقتصادية التي تجعلهن يتخلون عن التعليم وتؤدي بهن إلى الوقوع كضحايا للاستغلال والاتجار بهن.

د- بالنسبة إلى الدخل وإعالة الأسرة والانفاق عليها، اتضـح تدني الدخل الثهري

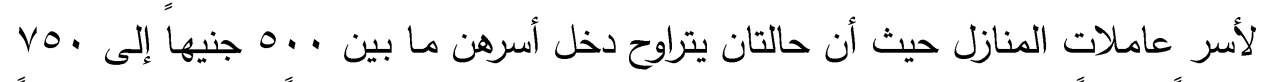

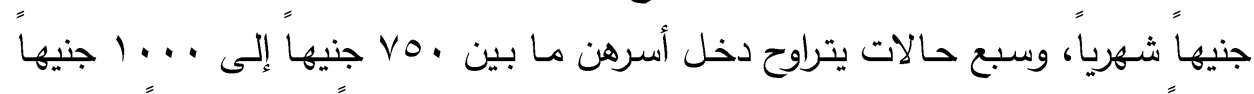

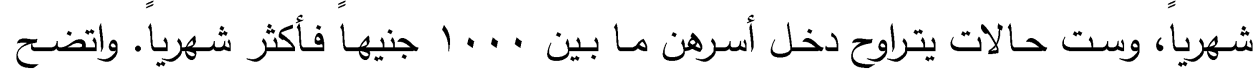
وجود مصادر دخل أخرى بخلاف العمل في الخدمة المنزلية حيث أكدت ثلاثة عشر حالة التئ على عمل الزوج أو عمل الأب, بالإضـافة إلى حصولهن على مساعدات من أهل الخير

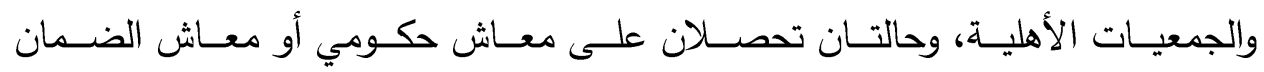
الاجتماعي. أما بالنسبة للإنفاق على الأسرة فإن حالتان الأرملتان يقدن بالإنفاق بمفردهن وإعالة أسرهن، في حين أجمعت بقية الحالات على أنهن يشاركن في المصاريف الأسرية الإنية

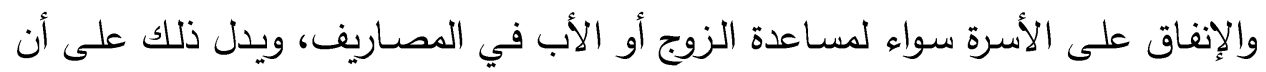

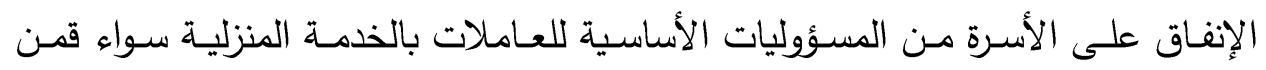

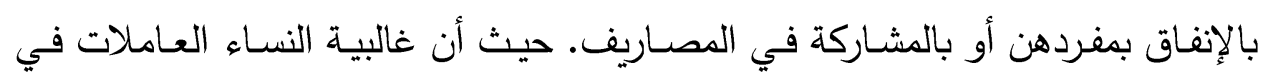

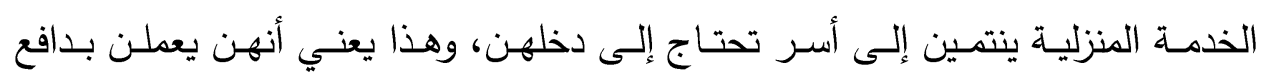
المشاركة في ميزانية الأسرة.

ويتفق ذلك مع دراسة (وفاء مرقص) التي تثير إلى أن أغلب النساء العاملات في

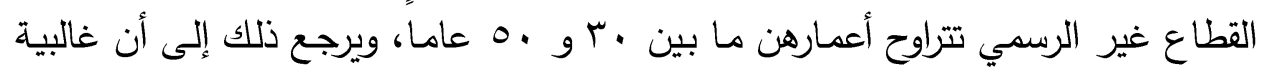

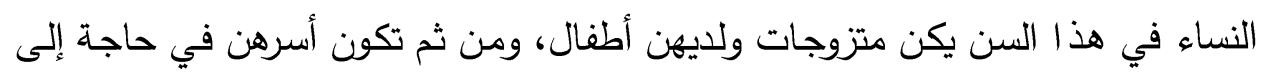

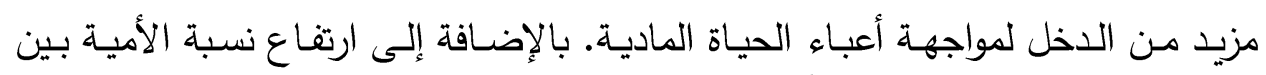

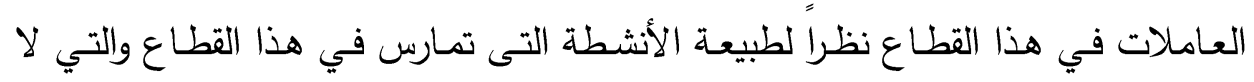

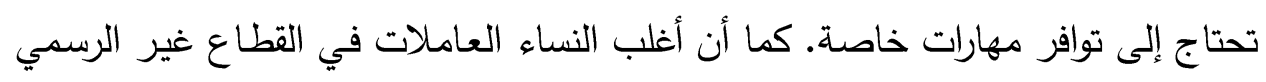


الاتجار بالنساء العاملات في الخدمة المنزلية الأسباب وسبل المواجهة: دراسة حالة بححافظة القاهرة

يكونوا من المتزوجات بافتراض أن أعباء الزواج والأبناء ومتطلبات الاسرة تدفعهن إلى العهل. إلى جانب أن بعضـهن يكون من المطلقات والأرامل اللاتي لا يمتلكن مصدراً

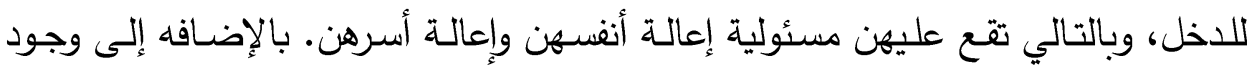
شريحة أخرى من غير المتزوجات يتجهن إلى العمل في هذا القطاع للإنفاق على أنفسهن بالئن

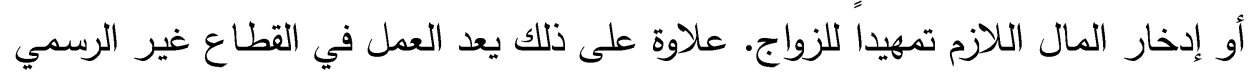

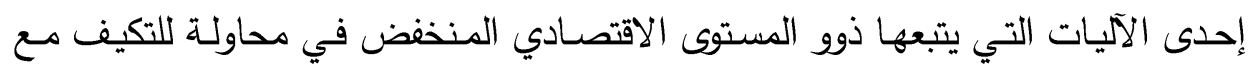
ظروف فقرهم، ومن ثم فإن غالبية النساء يعملن في هذا القطاع كوسيلة لكسب العيش ؛ـ وفي ضـوء ذلك تشير دراسـة (محيا زيتون) إلى أنـه في دول العالم الثالث يوجد

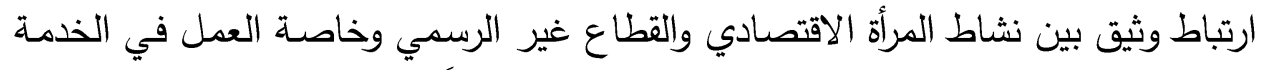

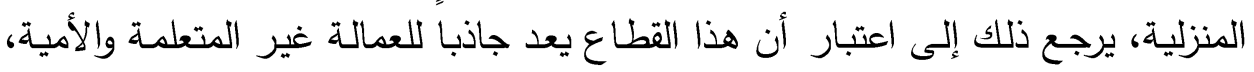

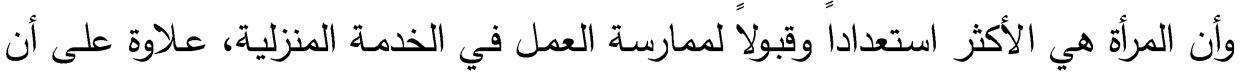
القطاع غير الرسمي يكون أكثر مرونـة من حيث أيام وساعات العهل, وهذا يلائم المرأة

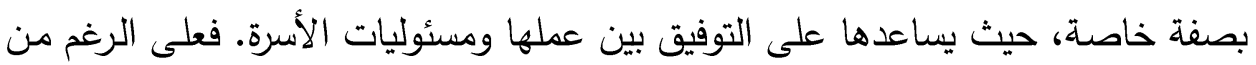
عيوب العمل في الخدمة المنزلية المتمثلة في إفتقاره للحماية والضمان الاجتماعي إلا أنها يتمتع بمزايا تجعله مصدر جذب، خاصـة للنساء من الفئات الفقيرة, حيث أن العمل في

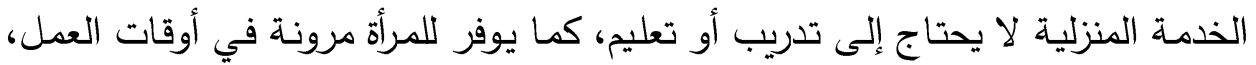

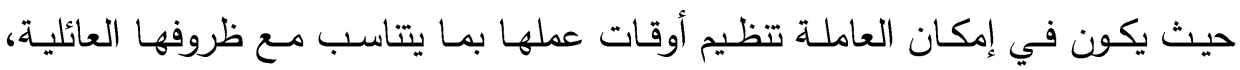

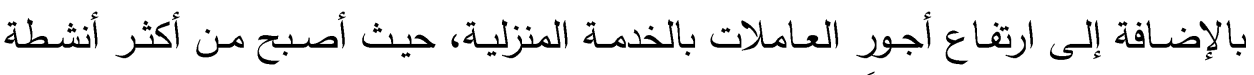

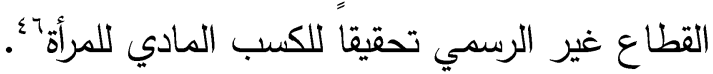

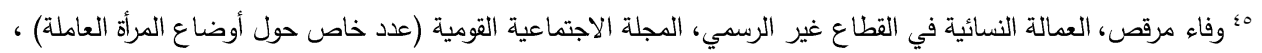

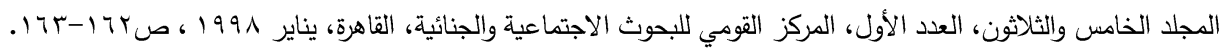

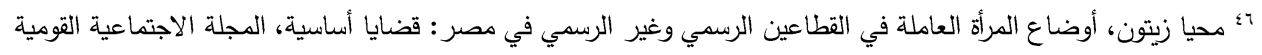

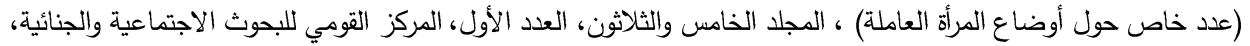

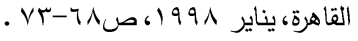

العدد السادس والعشرون (الجزء الثانى) •. r.

مجلة مجلة كلية التربية- جامعة عين شمس 
د/ هبه الله مصطفى محمد مصطفى

ثالثا: تحليل البيانات للإجابة على تساؤلات الدراسة:

ا-طبيعة العمل في الخدمة المنزلية وظروفه في مجتمع الاراسة:

استقراء حالات الدراسة يكثف عن تنوع وتعدد مهام العمل المنزلي التي تقوم بها

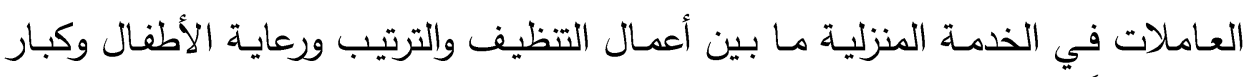
السن مرورا بطهي الطعام وغسل وكي الملابس حتى شراء المتطلبات المنزلية للأسرة.

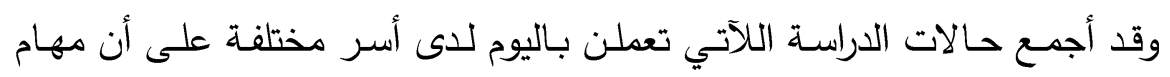

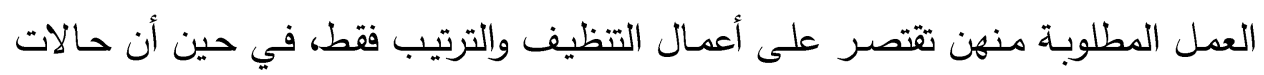

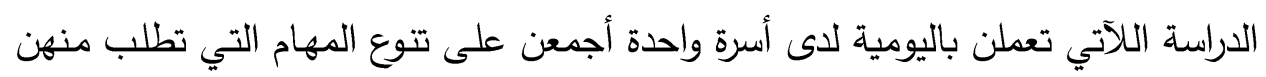
بين أعمال تنظيف وطهي الطعام ورعاية الأطفال.

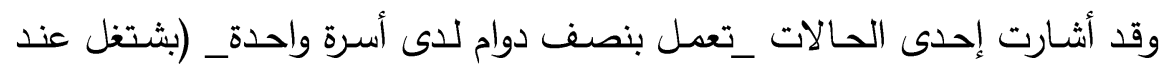

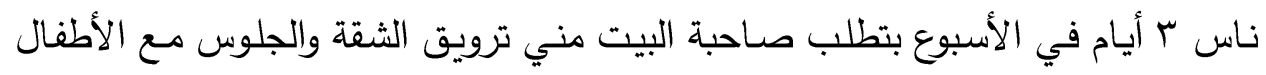

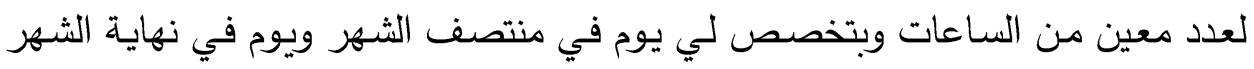
لتنظيف الثقة كلها وغسل السجاد والستائر ). وتقوم عـاملات المنـازل المقيمـات إقامـة دائهــة بمهام متعددة كـالتظظيف ورعايـة الأطفال وكبار السن وطهي الطعام. حيث شثير إحدى الحالات (بشتغل عند سيدة مسنة

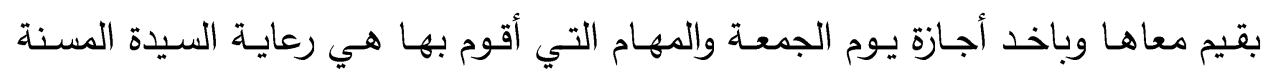

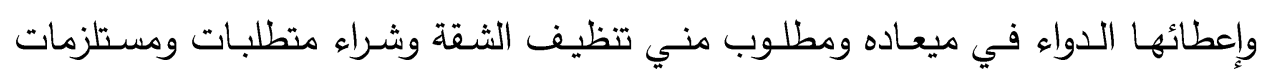

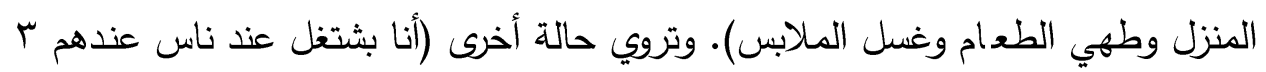

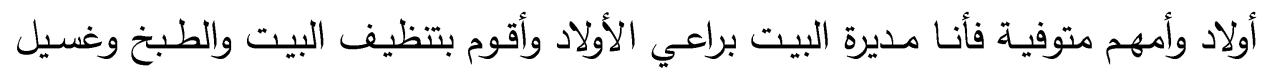

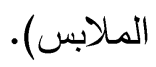
وفيما يتعلق بطبيعة الأجر الذي تحصل عليه العاملات في الذدمة المنزلية, أشار

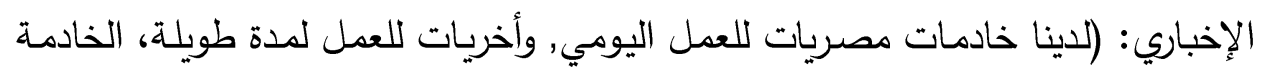

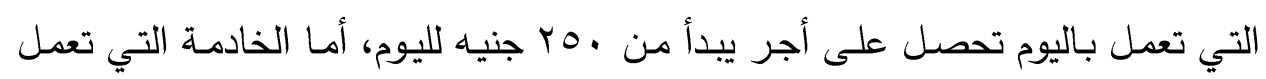

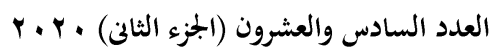

جملة جلة كلية التربية- جامعة عين شمس 
الاتجار بالنساء العاملات في الخدمة المنزلية الأسباب وسبل المواجهة: دراسة حالة بمحافظة القاهرة

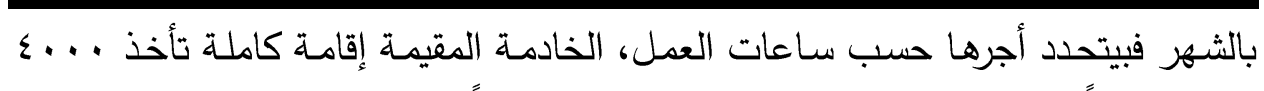

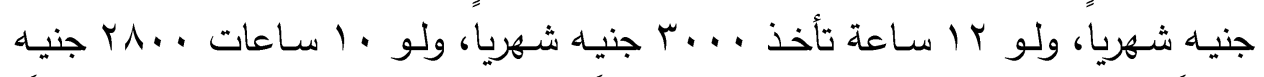

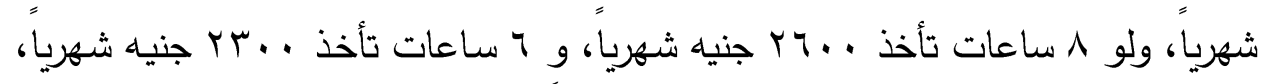

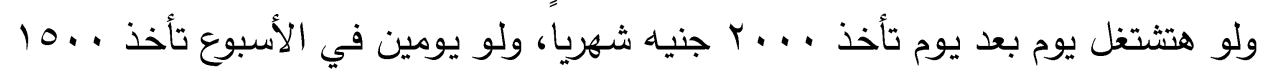

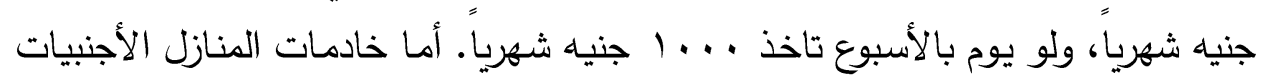

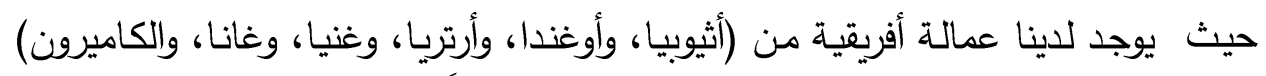

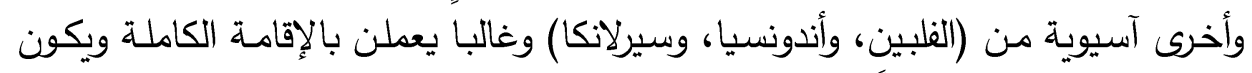

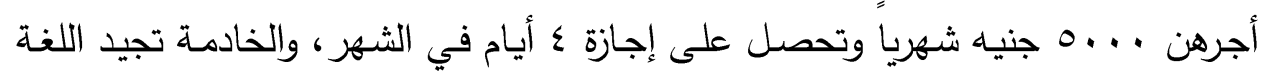

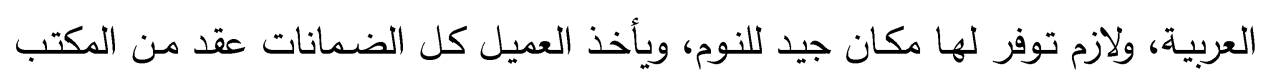
وأوراق ال UN الخاصـة بالخادمة، ويمكن للعميل استبدال الخادمة بأخرى في خلال شهور ). وتشير إحدى الحالات العاملة باليوم ( باخذ في تتظيف الشقة من . مr ل . . ع

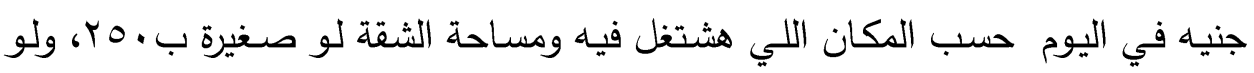

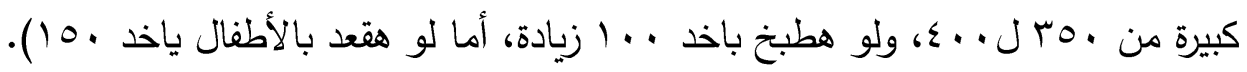

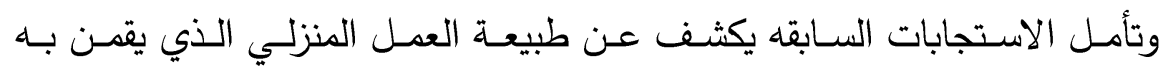

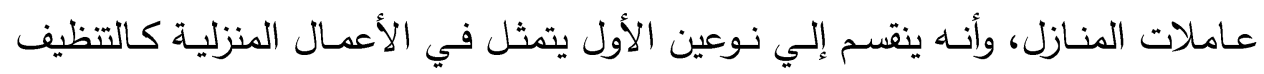

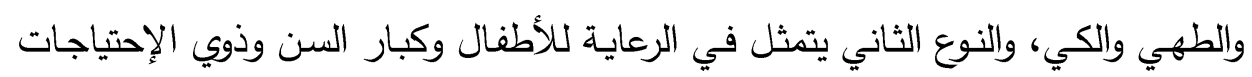
الخاصة.

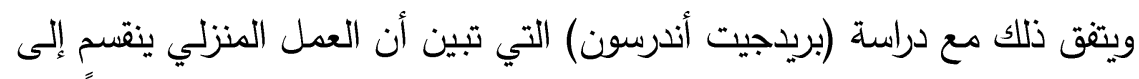

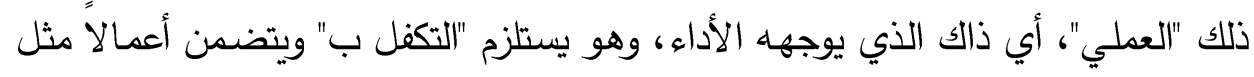

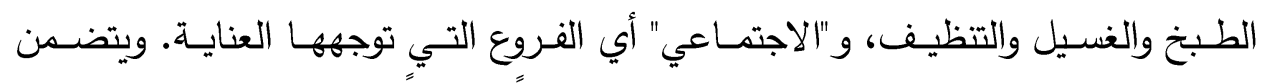

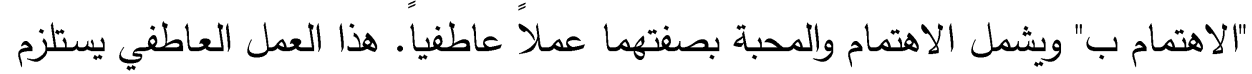

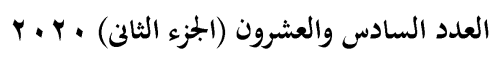

مجلة مجلة كلية التربية- جامعة عين شثس 
د/ هبه الله مصطفى محمد مصطفى

انخراطاً عاطفياً ولا يمكن تحقيقه دون حنان وعطف، حيث تحسن عاملات الرعاية من جودة الحياة في المنزل وتوفرن فائض عطف لأرباب عملهن وحأ.

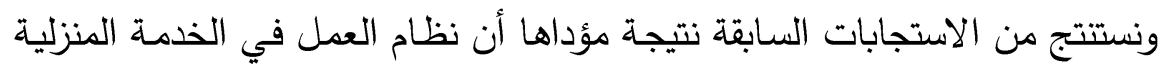

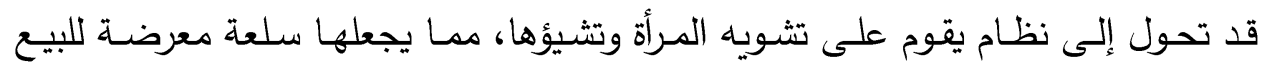

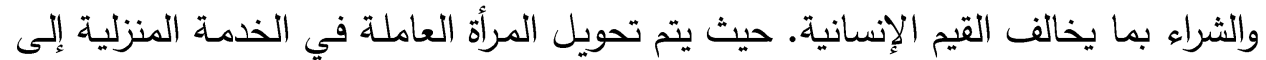
ماكينة عمل فقط، وإقصاء أي بعد إنساني لها. حيث تم إخضاع عاملات المنازل لمفهوم العرض والطلب والتعامل معهن في ساحات السوق الاقتصادي كثيء مفرغ من أي قيم،

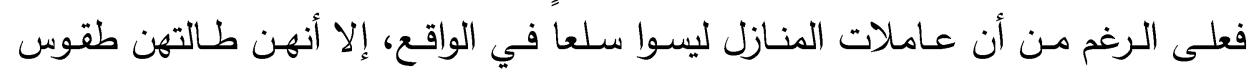

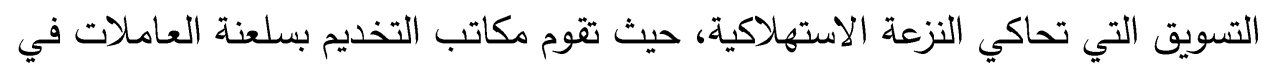

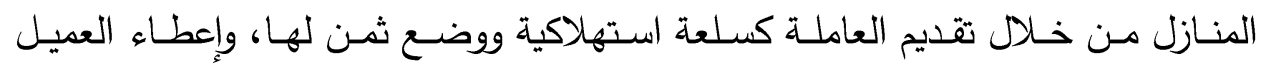
(صاحب المنزل) الحق بمقارنتها واستبدالها من أجل الحصول على العرض الأفضل الذي يقدم الخدمة بأفضل الميزات وأنسب الأسعار .

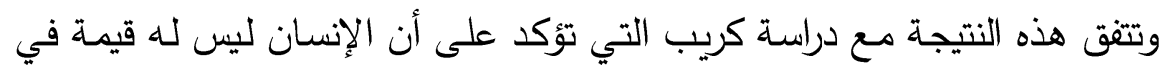
ظل الرأسمالية إلا بدوره في عملية الإنتاج والاستهلاك والربح المادي الناتج عنها. فنظام السوق في الرأسمالية يحول شبكة العلاقات الاجتماعية إلى شبكة من علاقات التبادل بين

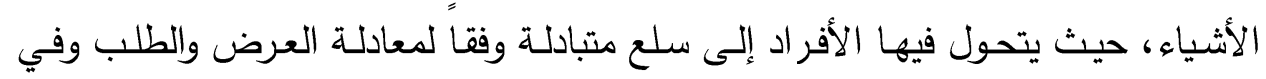

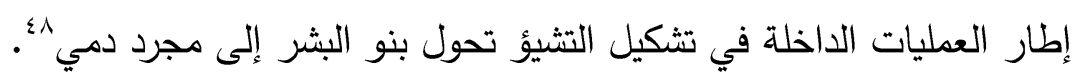
r- الوقوف على المبررات والأسباب:

تبين من خلال معطيات الدراسة الميدانية أن أهم الأسباب التي تدفع النساء للعمل

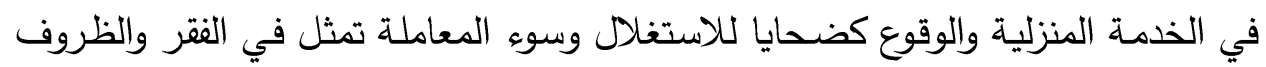

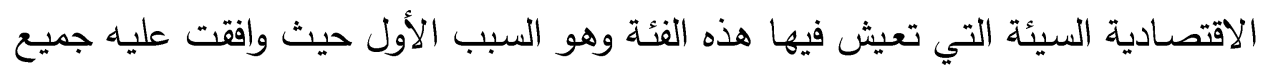

${ }^{47}$ Bridget Anderson, Doing the Dirty Work? The Global Politics of Domestic Labor, London: Zed Books, 2000.

^؛ إيان كريب، النظرية الاجتماعية، من بارسونز إلى هابرماس، ترجمة محمد حسن غلوم، مرجع سابق، ص219.

العدد السادس والعشرون (الجزء الثانى) • r. F

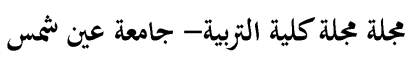


الاتجار بالنساء العاملات في الخدمة المنزلية الأسباب وسبل المواجهة: دراسة حالة بححافظة القاهرة

حالات الدراسة، في حين يتمثل السبب الثاني في ضعف مستوى التعليم حيث أن غالبية حالات الدراسة أميين لم ينالوا القسط الكافي من التعليم الذي يمكنهم من معرفة مـا لهن

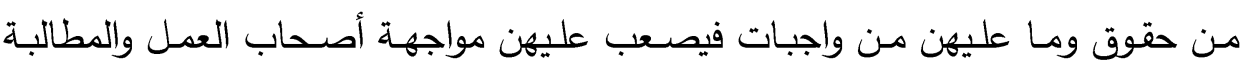
بالأجور المجزيـة مقابـل الجهد الذي يبذلوه، أو الشكوى إلى الجهات الهـات المختصـة للمطالبـة بحقوقهن مما يجعلهن عرضة للاستغلال من قبل أصحاب العمل. ويشير السبب الثالث إلى فرص العمل غير الكافيـة والبطالـة التي تعاني منها حالات الدراسـة وذويهم، وهذا السبب يترتب على انخفاض مستوى تعليم حالات الدراسـة الذي ينعكس على ضعف قدراتهن ومهاراتهن مما يجعل من الصعب عليهن وجود فرص عمل جيدة، ويدفعهن للعهـل في الخدمـة المنزليـة وتحمل مـا يتعرضـن لـه مـن مظـاهر

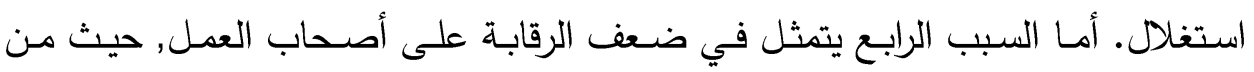

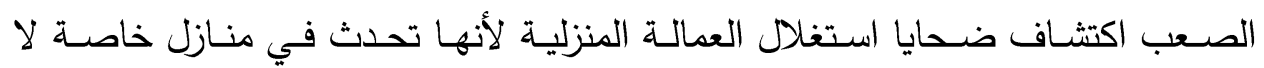
تخضـع للتنظيم والرقابـة من جانب السلطات العامـة، وهذا ينعكس على خوف خادمات المنازل من بطش صاحب العمل ووقوعهن ضحايا لاستغلال صاحب العمل. وفي ضوء ما سبق يتضح أن هناك العديد من الأسباب وراء اندفاع النساء للعمل في الخدمـة المنزليـة، وأهمها الفقر وانخفاض مستوى التحصيل العلمي ومستوى التأهيل المهني عند نسبة كبيرة من عاملات المنازل، الأمر الذي يتناسب مع إمكانية دخولهن في ولهي مجال العمل في الخدمة المنزلية دون فرض قيود عليهن، فقد أدت العولمة إلى تزايد دور

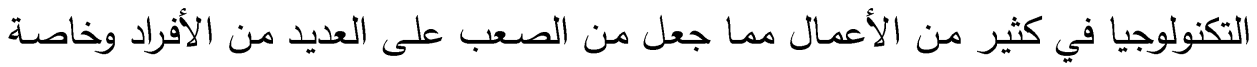
النساء أن يجدوا فرص عمل في القطاع الرسمي، ومن ثم يتجهون إلي خلق فرص تشغيل ذاتي ضمن قطاع غير منظم و فقا لقدراتهن ومهاراتهن المتدنية وبذلك تكون كثير من النساء مجبرون على العمل في الخدمة المنزلية بسبب ضـوط الحياة وظروفها القاسية وبدافع الرغبة في توفير دخل ملائم يوفر حياة كريمة لهن ولأسرهن. ووفقا لإحصائيات "الجهاز المركزى للتعبئة العامة والإحصـاء" كثفت نتائج بحث

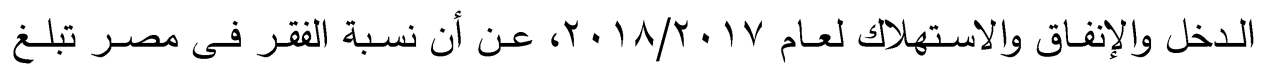




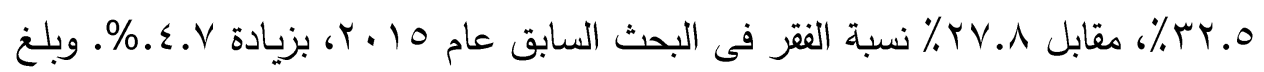

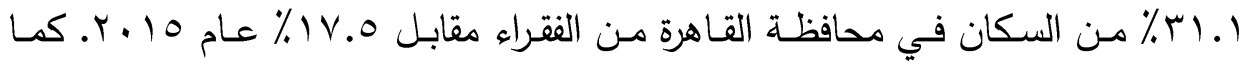

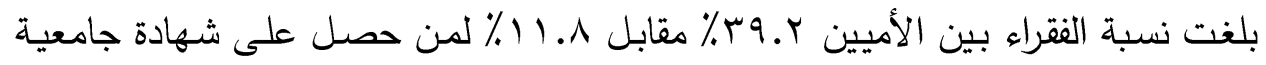

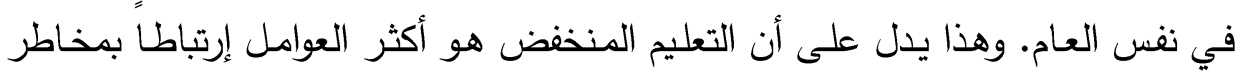
الفقر في مصر حيث تتـاقص مؤشرات الفقر كلما ارتفع مستوى التعليم. وبلغت نسبة

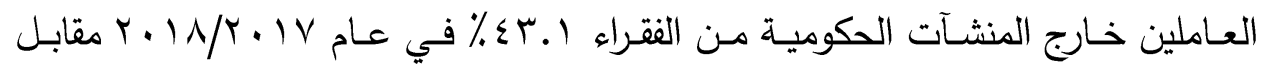

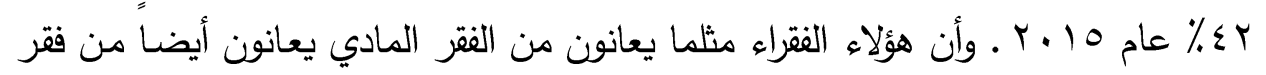

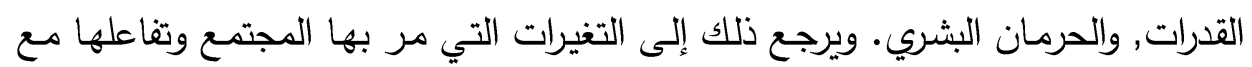

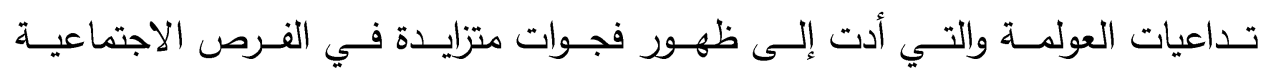

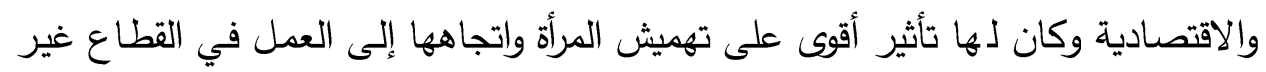

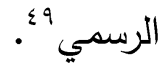
ويتفق ذلك مـع دراسـة (فاطمـة سلطان) التي تصف خصـائص تشـيل المـرأة في

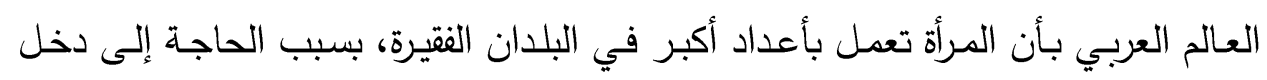
وبسبب هجرة العمال من الرجال إلى الدول الغنية.0. كما تؤكد دراسة (سهير أبو العينين) على أن أهم عوامل دخول المرأة لسوق العمل لـول

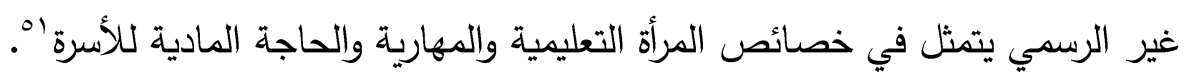

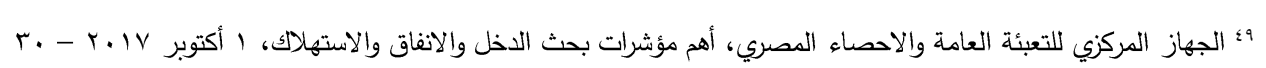

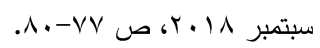

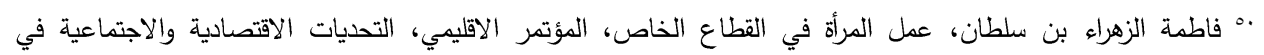

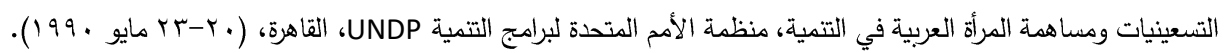

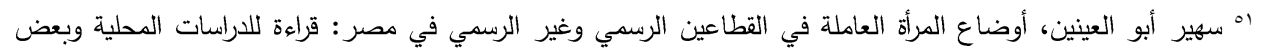

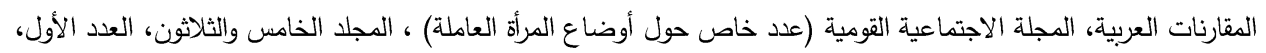

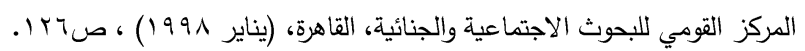


الاتجار بالنساء العاملات في الخدمة المنزلية الأسباب وسبل المواجهة: دراسة حالة بححافظة القاهرة

r- مظاهر الاستغلال التي تتعرض لها العاملات في الخدمة المنزلية:

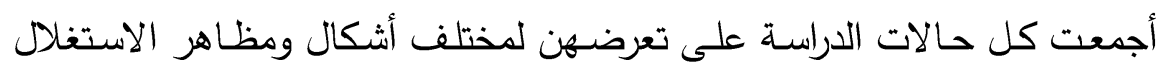

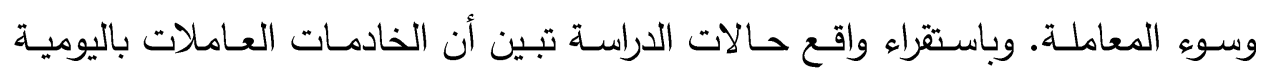
يتعرضن لبعض مظاهر الاستغلال من قبل ربة المنزل، وتتمثل هذه المظاهر والسلوكيات

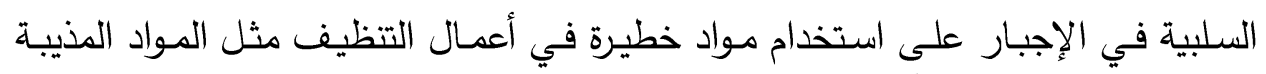
للدهون والتي تكون غالباً حارقة للجلد، وتكليفهن بأعمال تفوق طاقتهن، ومعاملتهن بقسوة التهات والسخرية من بعض تصرفاتهن، وتفتيش ملابسهن ومتعلقاتهن الثخصية، وعدم إعطائهن

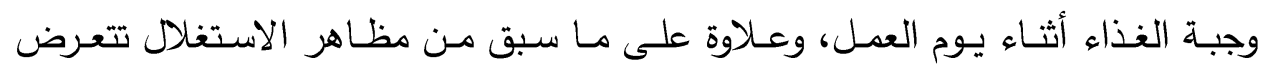

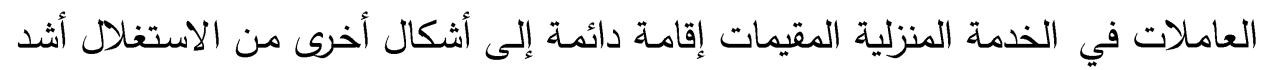

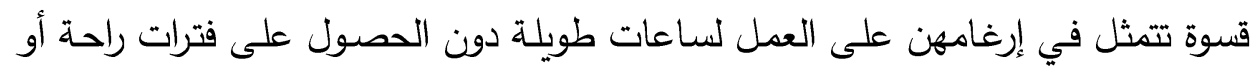

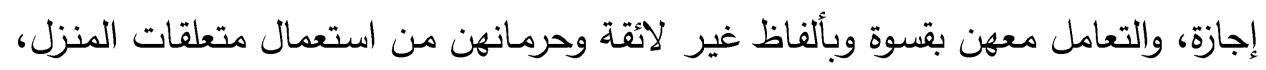

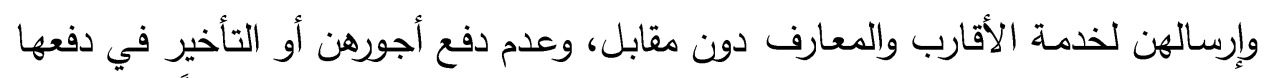

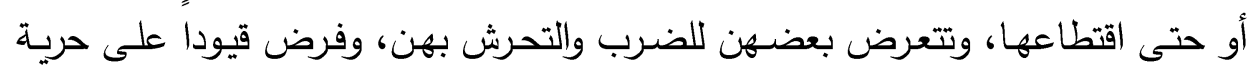
تتقلهن واتصالهن بعائلاتهن مما يجعلهن في عزلة قسرية. بالإضـافة إلى تعرض البعض لهض

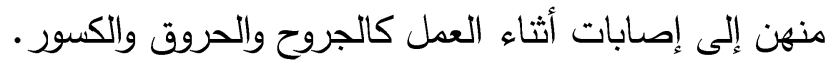

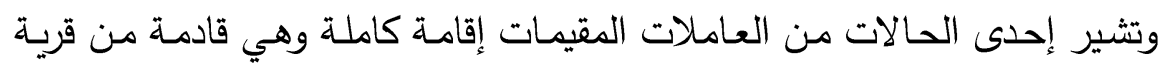
ريفية للبحث عن باب رزق تصرف منه على إخواتها (صاحبة البيت بتزعقلي وتشتمني

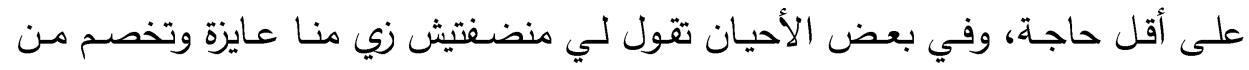

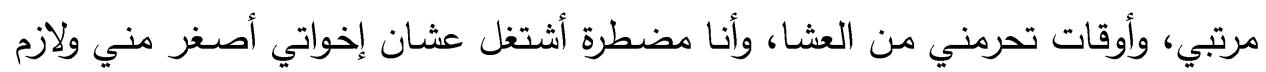
أساعد في أكلهم وتعليمهم). وتروي حالة أخرى _عاملة لدى أسرة واحدة نصف دوام_ـ (كنت بثتغل عند واحدة

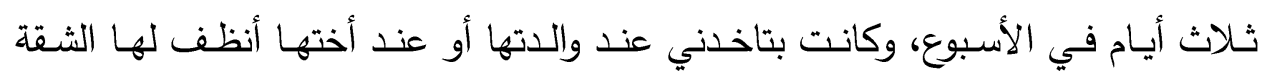
وأروقها أو أطبخلها بعد ما أخلص شغلي عندها، والثغل ده بدون مقابل ولما أقول لها 
تزود المرتب, تسخر من كلامي وتقول لي إنتي بتعملي إيه يعني عشان أزوده ده مجرد ترويق) وتأمل الاستجابات السـابقة يؤكد أن تعامل ربات المنازل مـع الخادمات المقيمات إقامـة دائمسة يكون أشد قسوة من تعاملهم مـع العاملات اللاتي يعملن باليوميـة أو بدوام جزئسي. حيث تحديـــ إقـامتهن داخـل البيـوت وفـرض قيـود على اتصـالهن بعـائلاتهن، وتعرضهن لمختلف أشكال الاعتداء اللفظي والبدني والجنسي, والحرمان من الطعام، أو

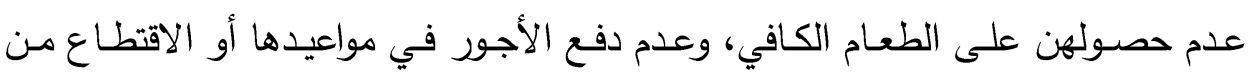

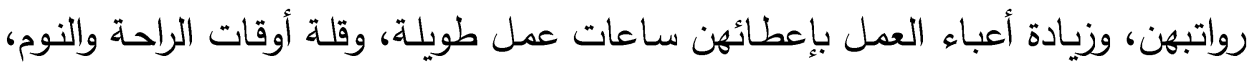

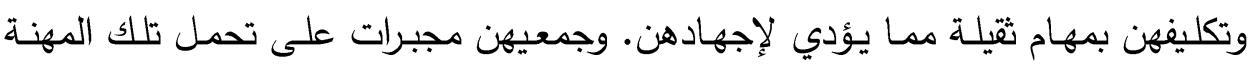
بصعوبتها والإهانة التي يتعرضن لها حتى يتمكن من الإنفاق على ذويهن.

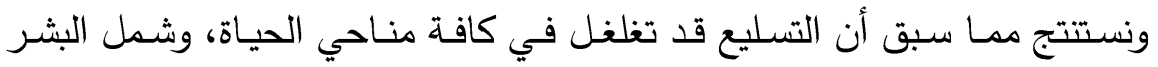
وجردهم من إنسانيتهم. حيث تتحمل المرأة العاملة في الخدمة المنزلية أبشع أشكال التسليع والاستغلال. إذ يتعامل أصحاب العمل معها بشكل يتضمن قدرا كبيرا من العبودية ويمثل

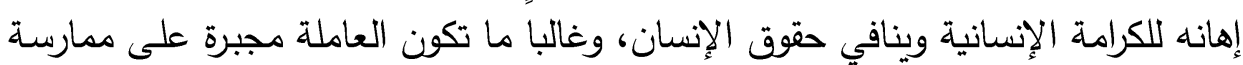
هذه الوظيفة بسبب ضغوط الحياة وظروفها القاسية. وتتفق هذه النتيجة مـع دراسة (سورينسن) التي تؤكد على أن ثقافة العولمـة التي

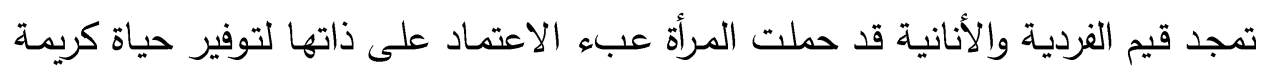

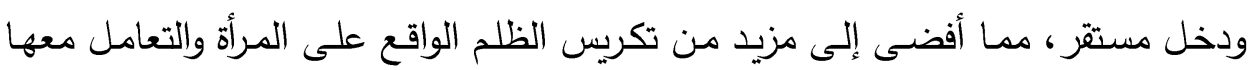
على إنها سلعة قابلة للعرض والطلب، والتمهيد لجرائم الاتجار بها واستغلالها وممارسه لونه

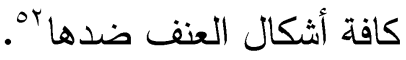

"or جيه سورينسن، معالجة الصلات المتداخلة بين العنف القائم على الجنس والاتجار بالبشر لمنع تكريس عدم المساواة، المشاورة

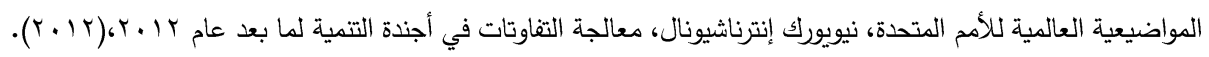

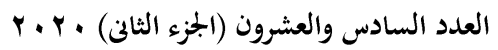


الاتجار بالنساء العاملات في الخدمة المنزلية الأسباب وسبل المواجهة: دراسة حالة بمحافظة القاهرة

كما تتفق مع دراسة (محيا زيتون) التي تؤكد على أن النساء العاملات في القطاع

غير الرسمي يتعرضن لسلبيات ومشاكل مختلفة تتمثل في:

-أن نشـاط العاملات في هذا القطاع يكون غير مرئي، حيث لانئ يوجد تسجيل رسمي لنشاط النساء وأحوالهن وظروف عملهن، ومساهمتهن في الاقتصاد القومي.

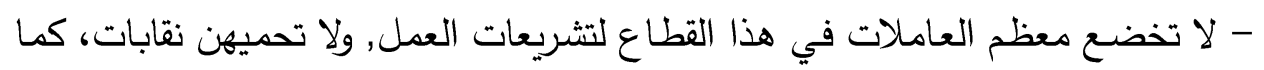
لا تتوافر لهن الخدمات الصحية. - تتعرض العاملات في هذا القطاع للاستغلال من جانب صـاحب العمل، حيث يدفع لهن أجور منخفضة. - تعمل النساء في هذا القطاع بدون عقود عمل وبشكل متقطع أو مؤقت، مما يجعلهن معرضون للاستغناء عنهن بسهولة.

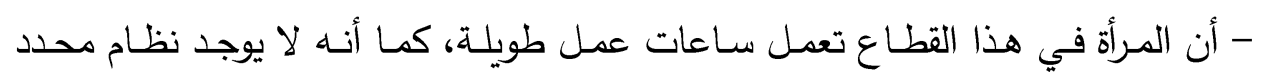
وواضح للإجازات مما يجعلها تتعرض للإجهاد هُه

؟ - الآثار الناجمة عن استغلال النساء العاملات في الخدمة المنزلية: يؤثر العمل في الخدمة المنزلية على إحداث مشكلات متعددة لعاملات المنازل في عدة جوانب اجتماعية ونفسية وصحية. وباستقراء حالات الدراسـة تبين حدوث مشكلات

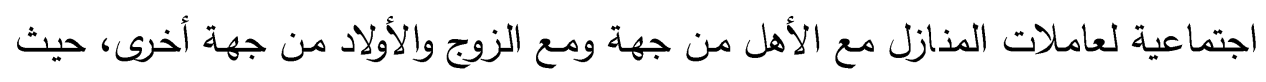
يؤثر العمل في الخدمة المنزلية على نقص رعاية العاملات لأبنائهن مما يعرض الأليه هن الأبناء

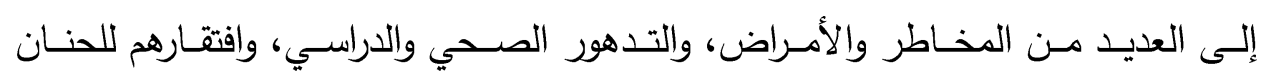
والأمان. كمـا يـؤثر العمـل في الخدمـة المنزليـة على إحـداث مشـكلات ومتاعـب نفسـية للخادمات، حيث تعاني جميع حالات الدراسة من القلق والتوتر والعصبية، والحزن والهم، لهونه ro محيا زيتون، أوضاع المرأة العاملة في القطاعين الرسمي وغير الرسمي في مصر : قضايا أساسية، مرجع سابق، ص .9-19.

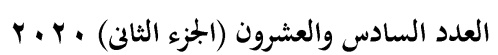

مجلة مجلة كلية التربية- جامعة عين شثس 
والخوف، والتشـاؤم مـن المستقبل. كمـا تتعرض عـاملات المنازل للعديد مـن المشكلات والمتاعب الصحية والجسمية، حيث أجمعت كل الحالات على أنهن يعانون من آلام في

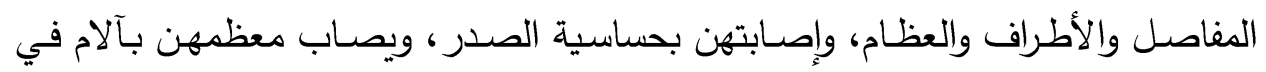
المعدة وأمراض في القلب.

وتقول إحدى حـالات الدراسـة (الثـغل في البيوت مجليش مـن وراه غير التعب، عظدي بيوجعني سواء ظهري ولا رجلي وعندي حساسية في الصدر مـن التراب اللي في لئي بشربه من التظظيف).

وتقول حالـة أخرى (أنـا على طـول خايفـة مـن بكرة وشـايلة الهـ، ومـش عارفـة

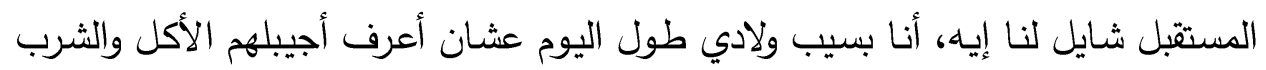

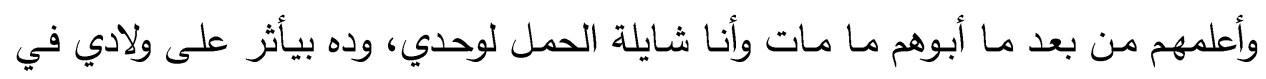
مرضهم ودراستهم).

ومما سبق نستتج أن المرأة في الطبقات الفقيرة تضطر إلى ممارسة النشاط غير

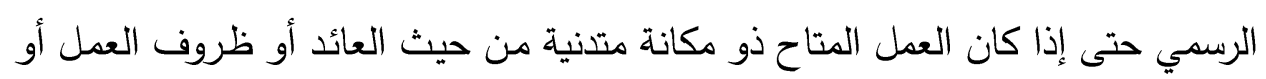

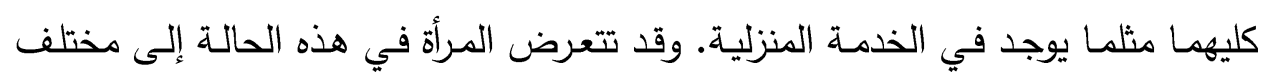

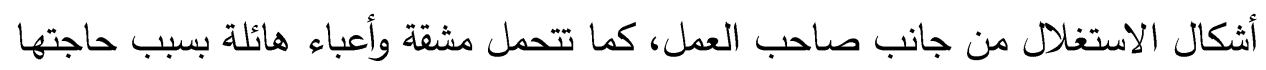
لكسب الاخل وتحملها مسئوليات الأسرة والمنزل في الوقت نفسه. وبالتالي تؤدي الضغوط

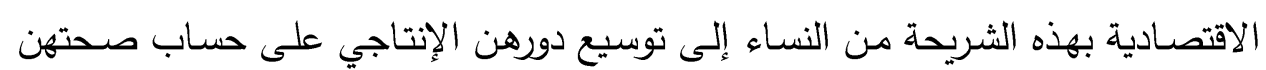
البدنية والنفسية؛ رابعاً: أهم ما توصل والنغية إليه البحث من نتائج:

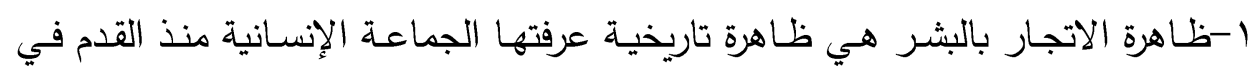

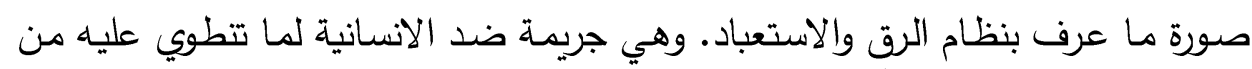

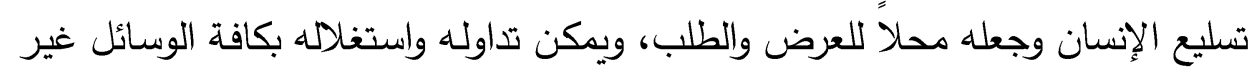

؛ُ محيا زيتون، أوضاع المرأة العاملة في القطاعين الرسمي وغير الرسمي في مصر : قضايا أساسية، مرجع سابق، صعه.

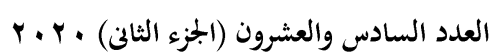


الاتجار بالنساء العاملات في الخدمة المنزلية الأسباب وسبل المواجهة: دراسة حالة بمحافظة القاهرة

المشروعة. ومن ثم فهي تمثل انتهاكا صريحا لحقوق الإنسان بما تتطوي عليه من إمتهان

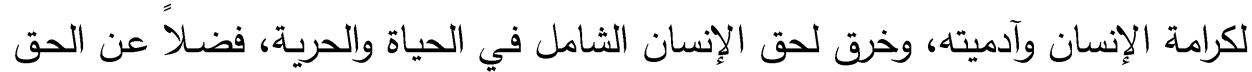

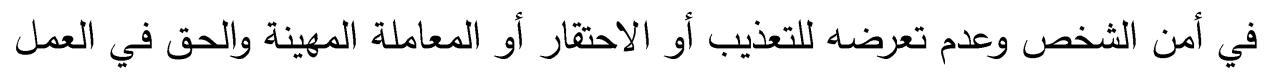
اللائق.

ץ- تعتبر ظاهرة استغلال النساء العاملات في الخدمة المنزلية شكلاً من أشكال الاتجار بالبشر • حيث تتوافر الأركان المادية لهذه الجريمة، فأكثر العوامل الكامنة خلف الاتجار بالبشر تتمثل في الفقر والتهميش والاستبعاد، فالأسر الأكثر فقرا وهامشية تكون أكثر

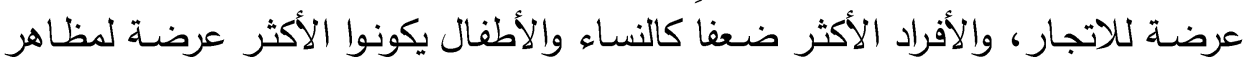

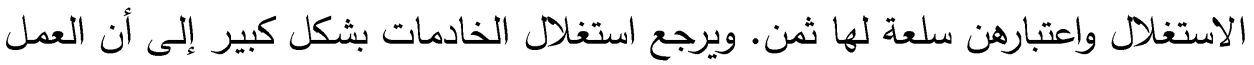

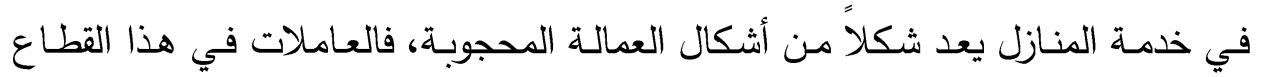

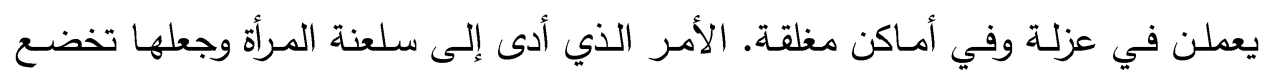
للعرض والطلب وتتعرض لكافة مظاهر الاستغلال وسوء المعاملة. ب- أن نظـام العمـل في الخدمـة المنزليـة قد تحـول إلى نظـام يقوم على تشـويه المـرأة وتشيؤها، ممـا يجعلها سلعة معرضـة للبيع والثراء بما يخالف القيم الإنسانية. حيث يتم تحويل المرأة العاملة في الخدمة المنزلية إلى ماكينة عمل فقط، وإقصاء أي بعد إنساني

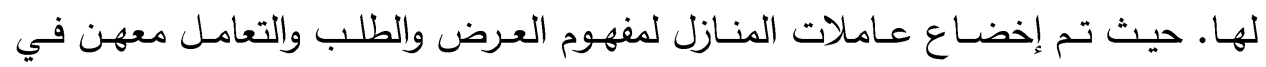
ساحات السوق الاقتصادي كشيء مفرغ من أي قيم، فعلى الرغم من أن عاملات المنازل ليسوا سلعا في الواقع، إلا أنهن طالتهن طقوس التسويق التي معرع من التحاكي النزعة الاستهلاكية، حيث تقوم مكاتب التخديم بسلعنة العاملات في المنازل من خـلال تقديم العاملـة كسلعة لهن

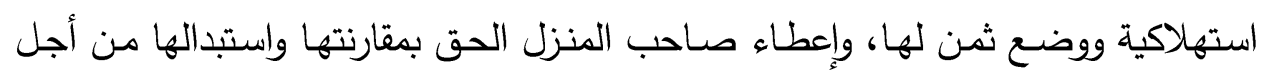
الحصول على العرض الأفضل الذي يقدم الخدمة بأفضل الميزات وأنسب الأسعار .

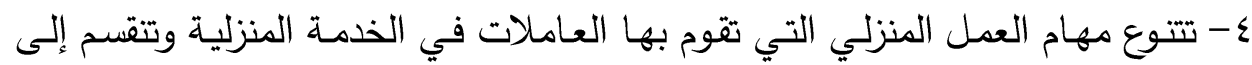

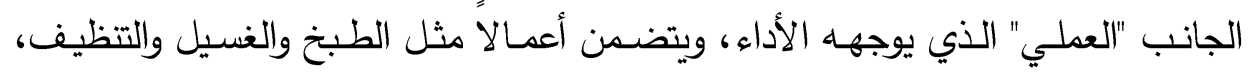

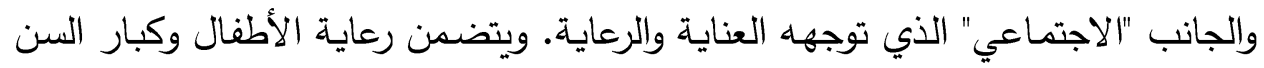

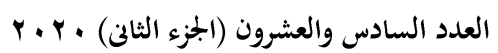

مجلة بجلة كلية التربية- جامعة عين شثس 
د/ هبه الله مصطفى محمد مصطفى

وذوي الاحتياجـات الخاصـة، ويشـل الاهتمـام والمحبـة بصفتهما عمـلاً عاطفيـاً لا يمكن تحقيقه دون حنان وعطف. ه- تتعدد الأسباب التي تكمن وراء اندفاع النساء للعمل في الخدمة المنزلية، وأهمها الفقر وانخفاض مستوى التحصيل العلمي ومستوى التأهيل المهني عند نسبة كبيرة من عاملات المنازل، الأمـر الذي يتناسب مـع إمكانية دخولهن في مجال العمل في الخدمة المنزلية دون فرض قيود عليهن، فقد أدت العولمة إلى تزايد دور التكنولوجيا في كثير من الأعمال

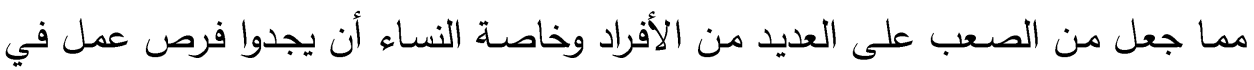
القطاع الرسمي، ومن ثم يتجهون إلي خلق فرص تشغيل ذاتي ضمن قطاع غير منظم

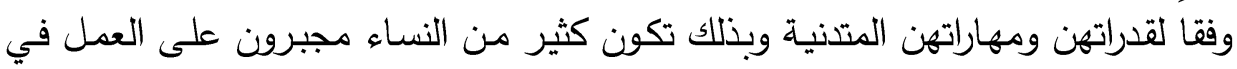
الخدمة المنزلية بسبب ضغوط الحياة وظروفها القاسية وبدافع الرغبة في توفير دخل ملانئ

$$
\text { يوفر حياة كريمة لهن ولأسرهن. }
$$

1- تتعرض النسـاء العاملات في الخدمـة المنزليـة لمختلف أثكال ومظاهر الاستغلال

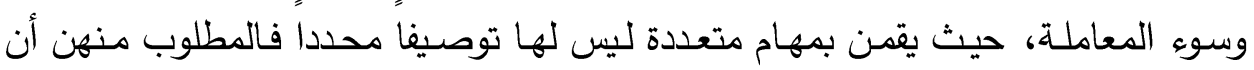
يقمن بما يطلب منهن دون مناقثة وعلى مدار اليوم، بالإضـافة إلى حرمـانهن من فترات

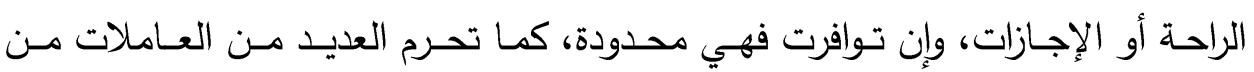

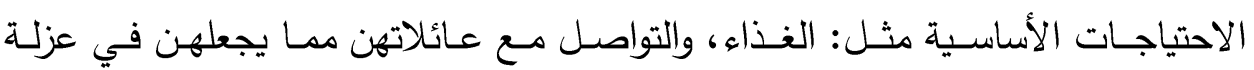

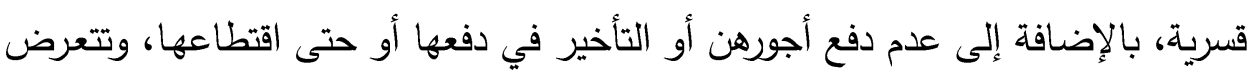
بعضهن للضرب والتحرش بهن، بالإضـافة إلى تعرض البعض منهن إلى إصلى إصـابات أثناء العمل كالجروح والحروق والكسور • لون V- يؤثر العمل في الخدمة المنزلية على إحداث مشكلات متعددة لعاملات المنازل في عدة جوانب اجتماعية ونفسية وصحية. فقد تبين حدوث مشكلات اجتماعيـة لعـاملات

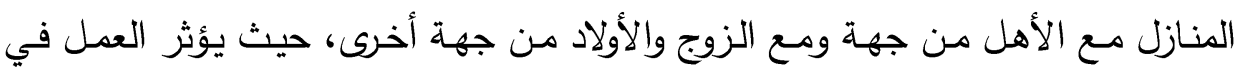

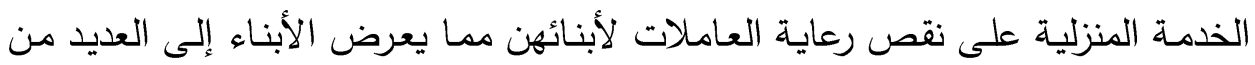

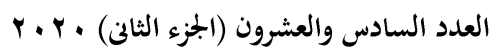

مجلة بجلة كلية التربية- جامعة عين شمس 
الاتجار بالنساء العاملات في الخدمة المنزلية الأسباب وسبل المواجهة: دراسة حالة بححافظة القاهرة

المخـاطر والأمـراض، والتدهور الصـحي والدراسـي، وافتقارهم للحنـان والأمـان. كما يؤثر على إحداث مشكلات ومتاعب نفسية للخادمـات، تثـمل القلق والتوتر ، والحزن والهم، والتثاؤم من المستقبل. كما تتعرضن للعديد من المشكلات والمتاعب الصحية والجسمية،

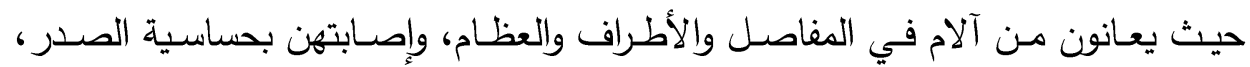
ويصاب معظمهن بآلام في المعدة وأمراض في القام فئب. خامساً: مقترحات وتوصيات لمواجهة استغلال عاملات المنازل ومكافحة الاتجار بهن:

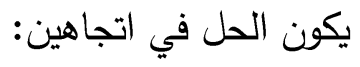

الاتجاه الأول: على مستوى المجتمع الدولي والمحلي (ما ينبغي أن يكون): ا-ضرورة تعزيز التعاون الدولي والإقليمي والمحلي، والتتسيق بين المؤسسات الحكومية وغير الحكومية المحلية والدولية لعقد جلسات حوارية حول كيفية التعامل مع ظاهرة الاتجار بالنساء العاملات في الخدمة المنزلية واستغلالكن، وتفعيل قنوات الاتصال بين وحدة مكافحة الاتجار بالبشر وكل من جهات إنفاذ القانون (وزارة العدل, وزارة القوى

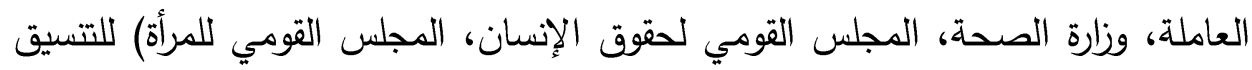
بينهم ومعرفة طبيعة علاقة ودور كل جهة من هذه الجهات في مكافحة جريمة الاتجار

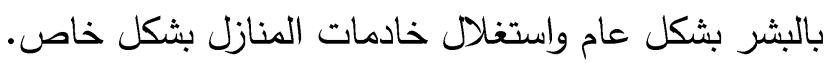
r- الاستفادة من تجارب الدول المتقدمة في مكافحة جريمة الاتجار بالبشر من خلال القيام بزيارات خارجية على المستوى الدولي للإطلاع على تجارب الدول المتقدمة والاستفادة منها وتبادل الخبرات بهدف تعزيز الإيجابيات لاينا وتدارك السلبيات للارتقاء بما هو أفضل لككافحة تلك الجريمة. r- اتخاذ الإجراءات التشريعية والتأمينية التي تضمن حماية عاملات المنازل حال عملهن، وتكفل حياة كريمة لهن بعد تقاعدهن. ع- اتخاذ إجراءات عملية من خلال إنهاء سوق الاتجار بالبشر، وهذا يتطلب من الحكومات أن تتعاطى مع جوانب ثلاثة: جانب العرض، وجانب التجار ، وجانب الطلب.

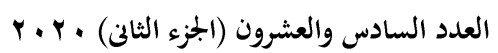

مجلة مجلة كلية التربية- جامعة عين شثس 
د/ هبه الله مصطفى محمد مصطفى

0- رفع الوعي بقضية الاتجار بالنساء وخاصة عاملات المنازل من خلال تقديم مضامين إعلامية بلغات مناسبة للجمهور المستهدف وأن تكون واضحة ومعبرة عن العارية أوضاع هذه العمالة وكيف يتم استغلالها، وإلقاء الضوء على معايير حقوق الإنسان الأساسية وتزويد عاملات المنازل بالمعلومات الضرورية لحماية أنفسهن من الاستغلال من قبل صاحب العمل وتوعيتهن بكيفية التماس الحماية من القانون.

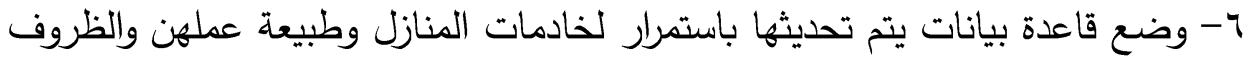
التي يعملن في ظلها. V- تخويل السلطة لدفتش العمل للقيام بحملات تنتيشية مفاجأة والدخول إلى المنازل للتأكد من ظروف تثغيل خدم المنازل وتطبيق عقوبات رادعة حال مخالفة القانون. 1- خلق آليات شكوى ومتابعة يسهل على خادمات المنازل الوصول إليها واستخدامها إذا لإنا تعرضن لأي مظهر من مظاهر القهر والاستغلال، كتوفير خط ساخن للتواصل عليه وتلقي أية بلاغات مع مراعاة الحفاظ على السرية التامة.

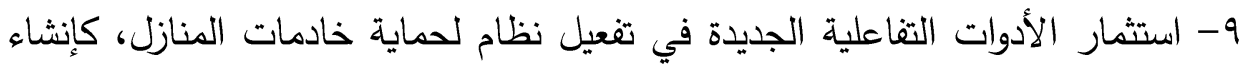
تطبيق لأجهزة المحمول يمكن خادمات المنازل من إدخال بياناتهن وتحديد مكان عملهن

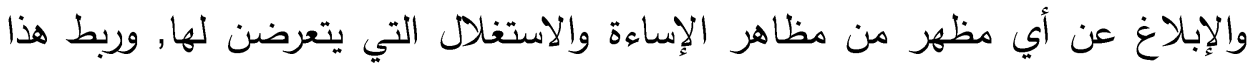

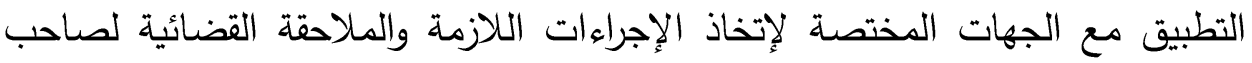

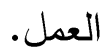

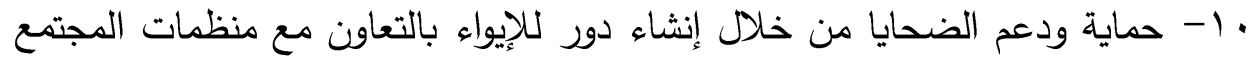

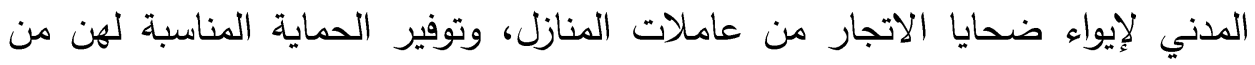

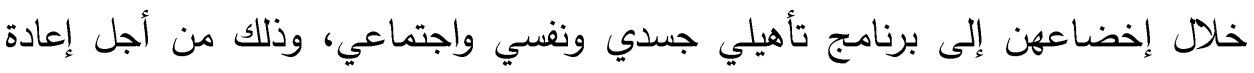

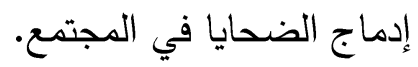

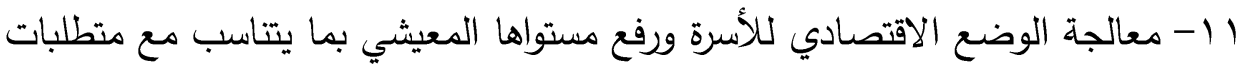

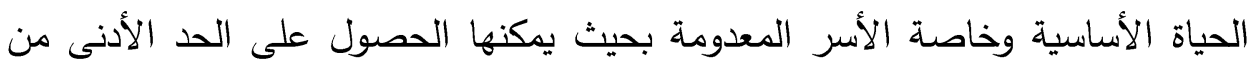

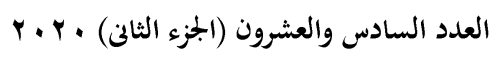

مجلة مجلة كلية التربية- جامعة عين شثس 
الاتجار بالنساء العاملات في الخدمة المنزلية الأسباب وسبل المواجهة: دراسة حالة بمحافظة القاهرة الدخل المطلوب لمواجهة احتياجاتها المعيشية الأساسية مما يحول دون وقوع أفراد الأسرة

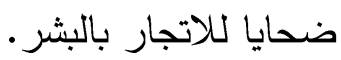

الاتجاه الثاني: على مستوى المرأة العاملة في الخدمة المنزلية (ما هو ممكن): ا-إعادة التأهيل المهني للنساء لتتاسب مهارتهن حاجات سوق العمل، مما يوجد لهن فرص عمل دائمة. r- التمكين الاقتصادي للمرأة من خلال مشاركة منظمات المجتمع المدني في تقديم برامج تشمل الفئات المهشة من النساء ذوات المهارات المتدنية، وعاملات المنازل، تهدف إلى تدريب هؤلاء النساء وتعليمهن حرف كالخياطة والتفصيل والأعمال اليدوية

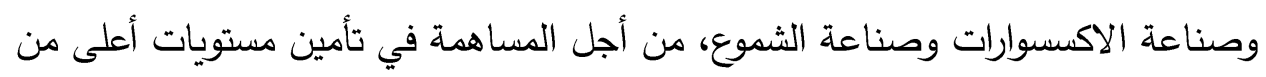
الاخل، وزيادة الأمن لديهن وحمايتهن من العنف. r- ضرورة دعم القروض الصغيرة للمشروعات الإنتاجية للنساء. 
د/ هبه الله مصطفى محمد مصطفى

\section{مراجع الاراسة}

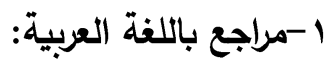

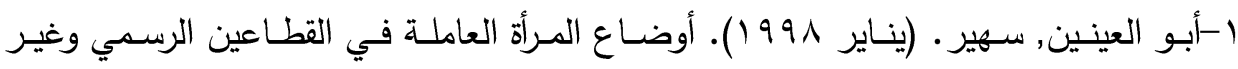

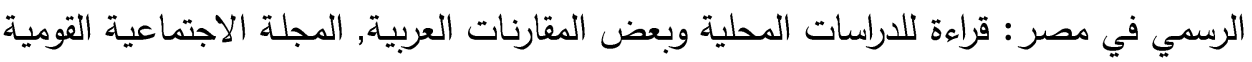
(عدد خاص حول أوضـاع المرأة العاملـة), المجلد الخـامس والثلاثون, العدد الأول, القـاهرة : المركز القومي للبحوث الاجتماعية والجنائية. r- الأصقه، أمنة بنت عبدالرحمن علي (7 1 ـ ب). هروب عاملات المنازل في منطقة الرياض

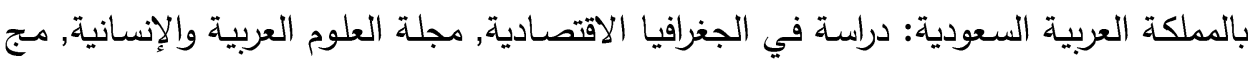

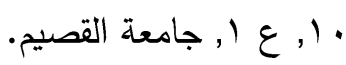
r- البحيري, أميرة محمد بكر • (11) • (1). الاتجار بالبشر وبخاصـة الأطفال من وجهة النظر العلمية النفسية والاجتماعية والقانونية, القاهرة: دار النهضة البرة العربية.

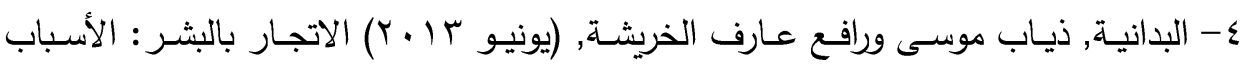

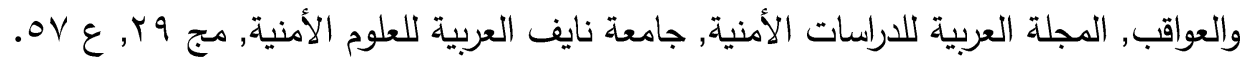

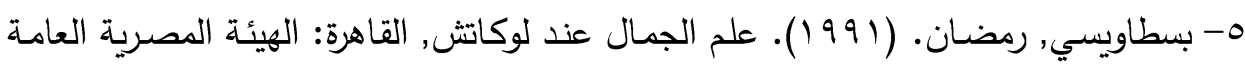
للكتاب.

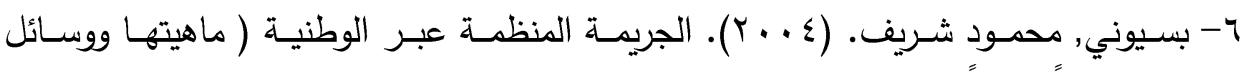
مكافحتها عربيا ودوليا ), القاهرة : دار الثروق.

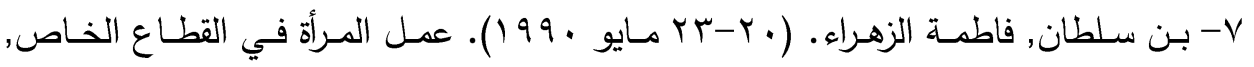

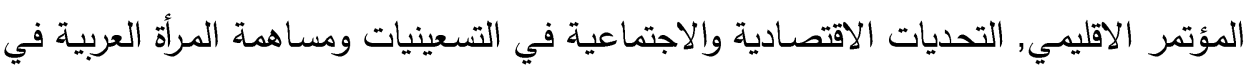
التمية, , القاهرة: منظمة الأمم المتحدة لبرامج التتمية UNDP.

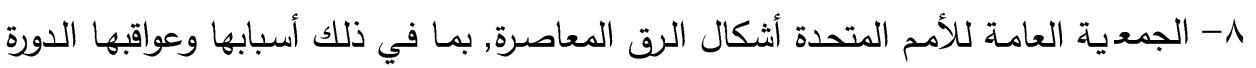

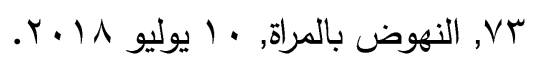

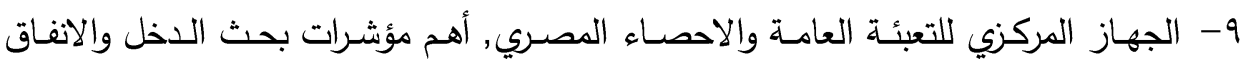

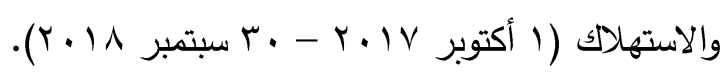

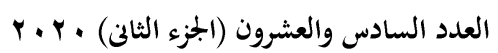

مجلة بجلة كلية التربية- جامعة عين شثس 


\section{الاتجار بالنساء العاملات في الخدمة المنزلية الأسباب وسبل المواجهة: دراسة حالة بمحافظة القاهرة}

• 1- حامد, حامد سيد محمد. (· ( • ( الاتجار في البشر كجريمة منظمة عابرة للحدود بين الأسباب والتداعيات, الرؤى الاستراتيجية, المركز القومي للإصدارات القانونية.

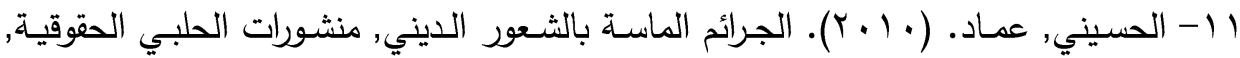

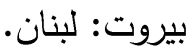

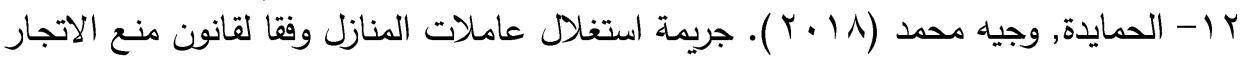

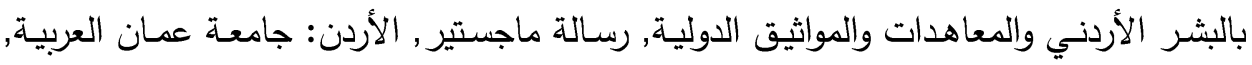
كلية القانون, عمان. r ا - الدبيات، أمل. (• ( • (؟). مشاكل الاتجار بالنسـاء في العالم العربي، الأكاديمية السورية الدولية: بحث مقدم لنيل درجة الدبلوم في الثؤون الدولية والدبلوماسية.

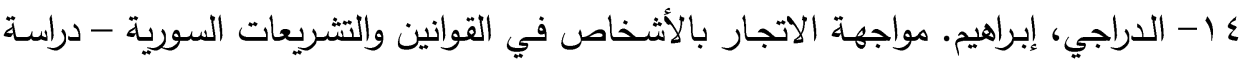
قانونية، منشورات المنظمة الدولية للهجرة.

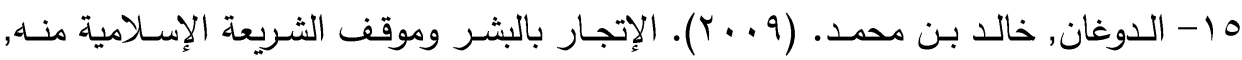

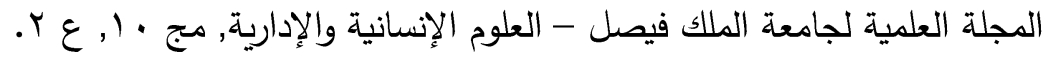

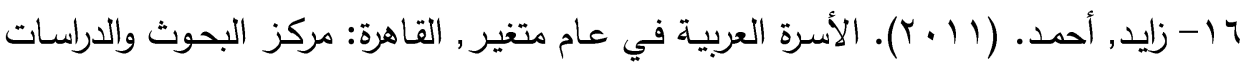

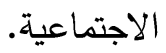

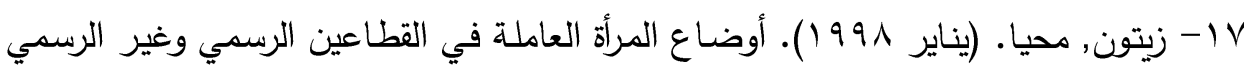
في مصر : قضايا أساسية, المجلة الاجتماعية القومية (عدد خاص حول أوضاع المرأة العاملة), المجلد الخامس والثلاثثن, العدد الأول, القاهرة: المركز القومي للبحوث الاجتماعية والجنائية.

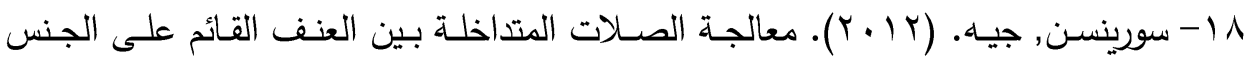

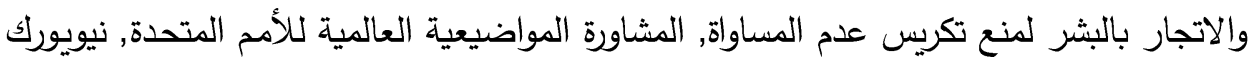

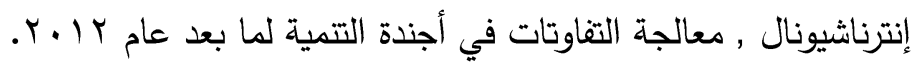

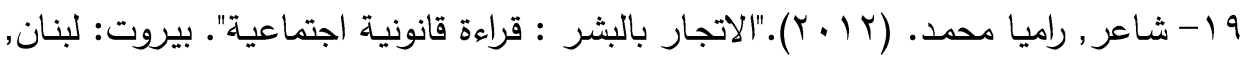
منشورات الحلبي الحقوقية.

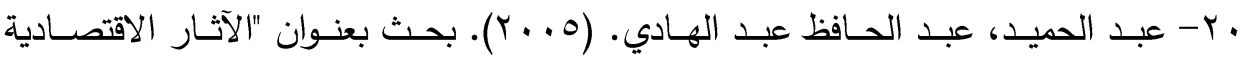

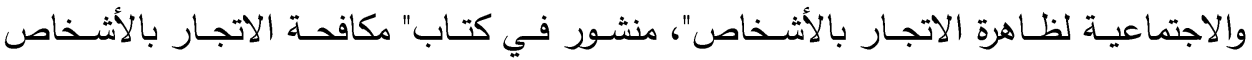
والأعضاء البشرية"، الرياض: جامعة نايف العربية للعلوم الأمنية.

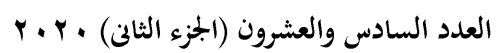




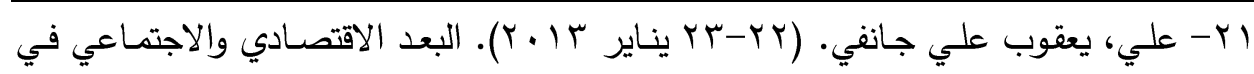
مكافحة الاتجار بالبشر : مفاهيم واتجاهات، ورقة بحثية ألقيت في. منتدى الدوحة الثالث لمكافحة

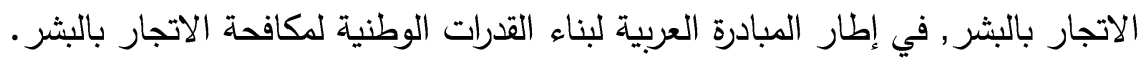

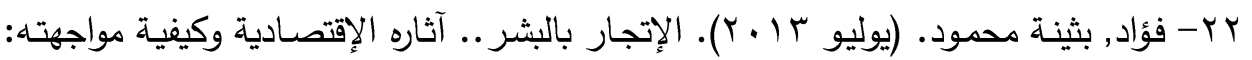
دراسـة تطبيقيـة على جمهوريـة مصر العربيـة, المجلـة العلميـة للاقتصــاد والتجارة, جامعـة عين العين

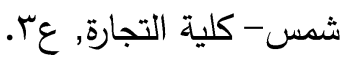
بr- كريب، إيان. (999 19). النظريـة الاجتماعية، من بارسونز إلى هابرماس. ترجمـة محمد حسن غلوم، العدد ؟ ؟ب, الكويت: سلسلة عالم المعرفة.

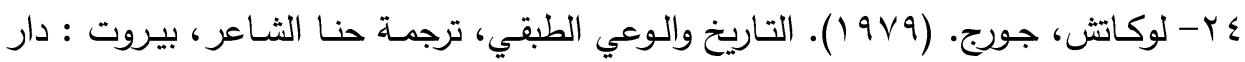

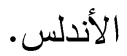

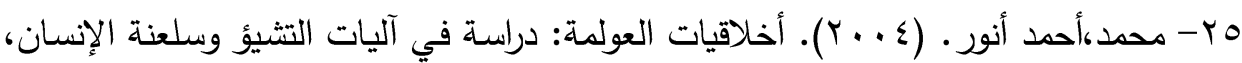
القاهرة : المحروسة للنشر والتوزيع. צr- محمد, سمر إبراهيم (ع ( • Y). الاتجار في النساء: رؤيـة قانونية, القاهرة: المركز العربي للبحوث والدراسات, آفاق سياسية. V V - مرقص, وفاء.( يناير 991 (1).العمالة النسائية في القطاع غير الرسمي, المجلة الاجتماعية القومية (عدد خاص حول أوضاع المرأة العاملة), المجلد الخامس والثلاثون, العدد الأول, القاهرة: المركز القومي للبحوث الاجتماعية والجنائية.

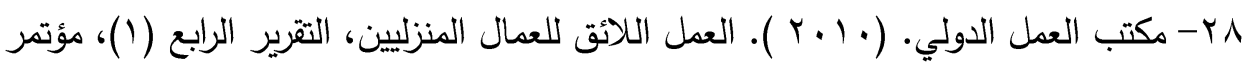

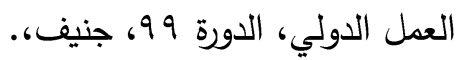

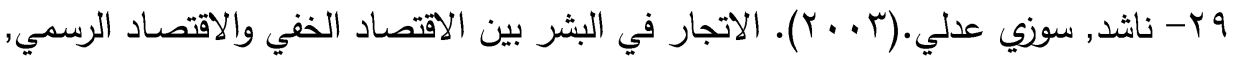

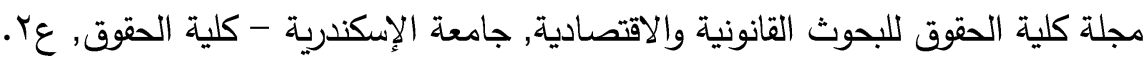

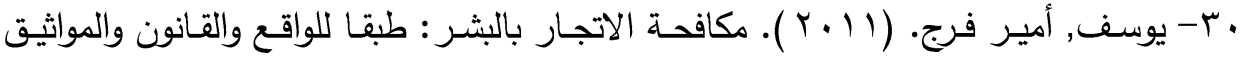
والبروتوكولات الدوليه, القاهرة: دار الكتاب الحديث. r - براجع باللغة الأجنبية: 1-Anderson, Bridget. (2001). Just another job? Paying for domestic work. Gender and Development, 9 (1), 25-33.

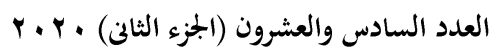


الاتجار بالنساء العاملات في الخدمة المنزلية الأسباب وسبل المواجهة: دراسة حالة بمحافظة القاهرة

2- Anderson, Bridget. (2000). Doing the Dirty Work? The Global Politics of Domestic Labor, London: Zed Books.

3- Budd, J. (2004). Achieving decent work by giving employment a human face. Geneva: International Labor Office.

4- Dobner, M., \& Tappert, S. (2010, September). Female migrant domestic workers and their Spanish employers in times of crisis. A comparative analysis of consequences for women on both sides of the coin. In Paper for the SGIR 7th Pan-European International Relations Conference, Stockholm, Sweden (pp. 9-11).

5- Fauve- Chamoux, A. (2004). Domestic service and the formation of European identity: understanding the globalization of domestic work in 16th -21 st centuries. Bern: Peterlang.

6- Honneth, Axel. (2005). La réification. Petit traité de théorie critique, traduit par Stéphane Haber, Paris: Gallimard.

7- International Labour Organization. (2017). Global estimates of modern slavery: Forced labour and forced marriage. Executive summary, Geneva.

8- International Labor Office. (2004). Gender and migration in Arab states: The case of domestic workers, Geneva: ILO.

9- International Labour Office. (2018). Ending forced labour by 2030: a review of policies and programmes, Geneva: ILO.

10- Pearson, Elaine. (2000). Human Rights and Trafficking in Persons: A Handbook, Bangkok, Global Alliance Against Traffic in Women (GAATW).

11- Rani, Ekta \& Rajni Saluja. (2017, October). A Study on Domestic Help Workers and Factors Affecting Realisation of their Rights in the 
د/ هبه الله مصطفى محمد مصطفى

State of Punjab, Jurnal of General Management Research, Vol.4, Issue 2, pp. $16-26$.

12- Roberts, D. (1997). Spritual and menial housework. Yale Journal of Law and Feminism, 9 (51), 22-36.

13- Safitri, M, Abdulrahman, N, \& Rokoduru, A. (2008). The hidden pillars: A study on the contribution of Indonesian domestic workers to the quality of life of Hong Kong and Malaysian Employers. A Project of Asia Pacific Forum on Women, Law and Development's Labor and Migration Task Force, Thailand.

14- Trafficking in Women and Children: The U.S and international Response. (May 10, 2000). P.1 Congressional Research service Report $98-649$ C. 
الاتجار بالنساء العاملات في الخدمة المنزلية الأسباب وسبل المواجهة: دراسة حالة بمحافظة القاهرة

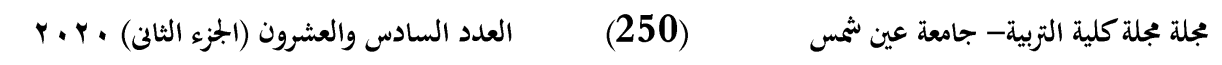

